\title{
Cyclostratigraphy of Shallow-Marine Carbonates - Limitations and Opportunities
}

\section{André Strasser}

Department of Geosciences, University of Fribourg, Fribourg, Switzerland

E-mail: andreas.strasser@unifr.ch

\section{Contents}

1. Introduction

2. The Cyclical Record in Shallow-Marine Carbonates 154

2.1 Factors Controlling Carbonate Production and Sedimentation 154

2.2 Repetitive (Cyclic) Sediment Accumulation 155

2.2.1 Allocyclic versus Autocyclic and Random Processes 158

2.2.2 Long-Term versus Short-Term Processes 159

2.2.3 Fragmentary Sedimentary Record 163

2.3 The Latemar Controversy 163

3. Case Study: Oxfordian of the Swiss Jura 164

3.1 Geological and Stratigraphic Context 164

3.2 Facies Evolution 165

3.3 Sequence- and Cyclostratigraphic Interpretation 166

3.4 Reconstruction of Orbitally Controlled Sea-Level Changes 170

3.4.1 Compaction and Decompaction 170

3.4.2 Estimation of Water Depth 171

3.4.3 Reconstruction of Accommodation and Sea-Level Changes 174

3.4.4 Sea-Level Amplitudes and the Orbital Signal 174

4. Discussion 176

5. Conclusions 179

Acknowledgments 181

References 181

\begin{abstract}
The sedimentary record of ancient shallow-marine carbonate platforms commonly displays a stacking of different facies, which reflects repetitive changes of depositional environments through time. These changes can be induced by external factors such as cyclical changes in climate and/or sea level, but also by internal factors such as lateral migration of sediment bodies and/or changes in the ecology of the
\end{abstract}


carbonate-producing organisms. If it can be demonstrated that the facies changes formed in tune with the orbital (Milankovitch) cycles of known duration, then a high-resolution time framework can be established. This demonstration is not an easy task because the orbital signal may be too weak to be recorded, or it may be distorted and/or overprinted by local or regional processes. The limitations of the cyclostratigraphical approach are discussed, but a case study from the Oxfordian of the Swiss Jura Mountains also shows its potential. A well-established chrono- and sequence-stratigraphic framework and detailed facies analysis allow identification of elementary, small-scale, and medium-scale depositional sequences that formed in tune with the precession, the short eccentricity, and the long eccentricity cycles, respectively. In the best case, a depositional sequence attributed to the precession cycle with a duration of $20^{\prime} 000$ years can be interpreted in terms of sequence stratigraphy. This then allows estimating rates of sea-level change and sedimentation within a relatively narrow time window, thus facilitating comparisons between ancient carbonate platforms and Holocene or Recent shallow-marine environments where such rates are well quantified.

\section{INTRODUCTION}

The repetitive stacking of beds observed in the sedimentary record has always fascinated geologists. Especially in hemipelagic settings, the regularly arranged limestone-marl alternations suggest that cyclical processes were at work and that these might reflect orbital (Milankovitch) cyclicity. Gilbert (1895) was the first to interpret such alternations in the Late Cretaceous Benton, Niobrara and Pierre formations of Colorado (USA) as being related to the precession cycle and thus could propose a time duration for these stratigraphic units. In shallow-water carbonates, it was Schwarzacher (1947) who first interpreted the hierarchical stacking of beds in the Late Triassic Dachstein (Austria) as having formed in tune with the precession and the short eccentricity cycles. Since these pioneering publications, hundreds of studies have dealt with the analysis and interpretation of repetitive, "cyclical" stacking of beds and facies in carbonates as well as in evaporites and siliciclastics, from shallow to deep, and from lacustrine to fluviatile to marine depositional systems. As the periodicities of the orbital cycles are known for today and for the geological past (e.g., Berger et al., 1989, 1992; Laskar et al., 2011), the cyclostratigraphic analysis allows for establishing astronomical time scales (e.g., Strasser et al., 2006; Hinnov and Ogg, 2007; Hinnov, 2013; Zeeden et al., 2015).

The prerequisite to correctly interpret the sedimentary record in terms of cyclicity and to attribute numerical values for the time represented by this 
record is to understand the processes that controlled sedimentation. The orbital cycles commonly invoked in cyclostratigraphic studies are caused by the precession of the equinoxes relative to the perihelion and aphelion of the Earth's orbit around the Sun, changes in the obliquity of the Earth's axis, and the shorter- and longer-period changes in the eccentricity of the ellipse on which the Earth travels around the Sun (e.g., Hays et al., 1976; Schwarzacher, 1993, 2000; Strasser et al., 2006; Hinnov, 2013). These cycles are responsible for changes of the solar irradiance on top of the atmosphere (Milankovitch, 1941). From there, this signal is transferred to the sedimentary environment through complex interactions and feedback mechanisms in the atmosphere, the hydrosphere, the cryosphere, and the biosphere (e.g., Pisias and Shackleton, 1984; Strasser, 1991; Sames et al., 2016; Wendler and Wendler, 2016).

In the hemiplegic realm, limestone-marl alternations commonly reflect repetitive changes in the carbonate-clay ratio. Clay input from the hinterland is controlled mainly by the activity of rivers, which in turn is influenced by rainfall and vegetation cover; clay distribution in the ocean then depends on sea level, tides, and oceanic currents. The carbonate ratio depends on the productivity of planktonic organisms (controlled by water temperature and nutrients), and/or on export of carbonate mud from shallow platforms (influenced by sea level, tides, and currents; e.g., Milliman et al., 1993; Pittet et al., 2000). Orbital cycles have a direct control on the climate (via the heat distribution in the atmosphere) and thus on rainfall, vegetation, and glaciation. Latitude, orography, and ocean-land distribution are additional factors. Sea-level changes result from glaciation-deglaciation cycles but also from thermal expansion and contraction of the ocean water, from retention and release of water in aquifers, and from changes in deep-water circulation (Sames et al., 2016). Nutrient distribution in turn depends on terrigenous input and upwelling of deep ocean waters. Once the sediment is deposited, the carbonate-clay ratio may be modified by diagenesis (carbonate being dissolved at the contact with the clay minerals and migrating to the carbonate-rich levels), thus enhancing the limestone-marl contrast (Einsele and Ricken, 1991).

In theory, limestone-marl alternations should reflect the orbital cycles quite faithfully, although some lag may occur before the sedimentary system reacts to the insolation signal. Time-series analysis can be performed on proxies of clay input (gamma ray, magnetic susceptibility, colour), and/or by considering the thickness of the carbonate beds as a proxy of planktonic productivity and/or mud export from the platform. However, there are 
caveats: If the orbital forcing is not strong enough to pass the signal on to the depositional environment and create a contrast in facies or geochemical signature, orbital cycles will not be recorded (or the record is so faint that it cannot be detected). In condensed intervals, the record of several cycles may be amalgamated and become undecipherable. One climatic or one sea-level cycle in tune with one orbital cycle may have two or more windows within which clays or carbonate mud are shed into the hemipelagic realm, or within which planktonic productivity is stimulated, meaning that one orbital cycle may be represented by two or more limestone-marl couplets (e.g., Pittet and Strasser, 1998a). In addition, diagenesis may distort the limestone-marl contrasts or even create alternations independently of orbital forcing (Westphal et al., 2004).

If there are no tectonic or synsedimentary disturbances (such as slumps), hemipelagic sections are well suited for establishing astronomical time scales (e.g., Cotillon, 1987; Huang et al., 1993, 2010; Martinez et al., 2015). The biostratigraphic and isotopic (mainly $\delta^{13} \mathrm{C}$ ) frameworks generally are well established and allow for basin-wide correlations.

Compared to the relatively simple system of hemipelagic limestone-marl alternations, the deciphering of the shallow-marine record of orbital cycles is much more challenging. In the following chapter, the many difficulties in identifying an orbital signal on shallow carbonate platforms will be discussed. A case study (Chapter 3) will then show how these difficulties may be dealt with and what the potential of the cyclostratigraphic approach can be.

\section{THE CYCLICAL RECORD IN SHALLOW-MARINE CARBONATES}

\subsection{Factors Controlling Carbonate Production and Sedimentation}

In shallow-marine, carbonate-dominated sedimentary systems, most of the carbonate is produced by organisms (e.g., Bathurst, 1975; Tucker and Wright, 1990; Flügel, 2004). From the viewpoint of these organisms, important life-sustaining parameters are:

- water temperature (controlled by air temperature and heat distribution through currents);

- water depth (controlled by relative sea level and sediment accumulation);

- water transparency (controlled by terrigenous input and/or planktonic productivity);

- water energy (controlled by waves and wind- or tide-generated currents); 
- sunlight for photosynthesis (controlled by latitude, water depth and water transparency);

- chemical composition of the water $\left(\mathrm{pH}, \mathrm{Ca}^{2+}, \mathrm{Mg}^{2+}, \mathrm{CO}_{3}{ }^{2-}, \mathrm{SO}_{4}{ }^{2-}\right.$, $\mathrm{O}_{2}$, and trace-element concentrations controlled by river input, ocean currents, evaporation, or recycling within the environment);

- nutrients (controlled by terrigenous input, upwelling, or recycling within the environment);

- type of substrate (soft, firm or hard depending on sediment type, sedimentation rate, and early diagenesis);

- ecological coexistence or competition (depending on the organisms involved).

Many of the above-mentioned parameters are themselves controlled by climate (hot, cold, humid, arid, seasonal, storm frequency and force), by the hinterland (furnishing siliciclastics and nutrients), by oceanic currents (distributing heat and nutrients), by relative sea level (defining water depth and influencing tidal regime), and by the morphology of the coastline and the platform (modifying currents and sediment distribution). As already mentioned, sea level itself is at least partly connected to climate through water stored in ice caps, alpine glaciers, and aquifers, and through thermally-controlled volume changes in the ocean water. The ecological factors follow the evolution of ecosystems through geological time.

Climate thus has a major, direct or indirect influence on carbonate production and sediment accumulation, and climate itself is controlled by the insolation changes that follow the orbital cycles in the Milankovitch frequency band. It has to be considered, however, that the atmospheric cells (Hadley, Ferrel, and polar) and, consequently, the high-pressure and lowpressure zones shift as a function of insolation (Matthews and Perlmutter, 1994). For example, while climate changes throughout one insolation cycle are small at the equator (very humid to humid), they are more pronounced at around 20 degrees latitude (i.e., from humid at the climatic maximum to arid at the climatic minimum). When interpreting cyclostratigraphic patterns it is therefore important to consider the paleolatitude of the study area. Furthermore, regional climate is influenced by the ocean-land distribution, oceanic circulation, and orography (e.g., Matthews and Perlmutter, 1994; Feng and Poulsen, 2014).

\subsection{Repetitive (Cyclic) Sediment Accumulation}

Once produced, the carbonate sediment can either stay in place (as in the case of microbial mats, reefs, or low-energy lagoons), may be rolled back 


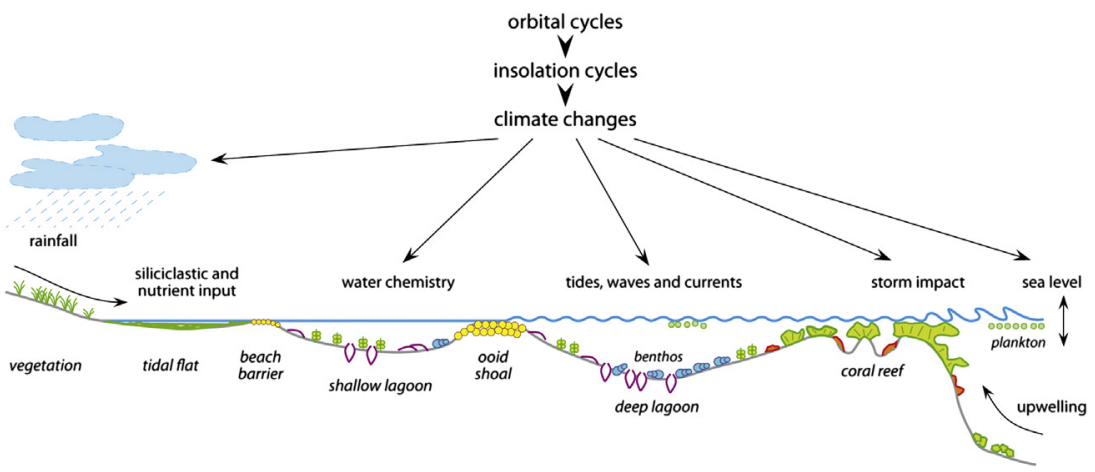

Figure 1 Sketch of platform transect illustrating the main parameters that influence carbonate production by benthic and planktonic organisms, and sediment distribution. Parameters independent of orbital cycles (such as tectonics or volcanic activity) are not considered.

and forth as on ooid and bioclastic shoals, or is removed from the production area by currents. Through time, the sediment will accumulate vertically and/or laterally, will possibly be reworked by waves, currents, and bioturbation, and will finally be stabilized through microbial mats, shallow burial, and/or early diagenesis. The resulting vertical and lateral facies changes are the record of changing environmental conditions as mentioned in Chapter 2.1 (Fig. 1).

A "depositional sequence" is here defined as a facies succession that translates facies changes (deepening- then shallowing-up), or that represents aggradation of sediment without facies change and is delimited by marly seams or distinct surfaces (Strasser et al., 1999). A depositional sequence is independent of scale and can, if facies changes and diagnostic surfaces allow for it, be interpreted in terms of sequence stratigraphy (Mitchum and Van Wagoner, 1991; Posamentier et al., 1992). A priori, a depositional sequence is descriptive and does not imply any interpretation in terms of cyclostratigraphy. The term "cycle" is here used to describe a repetitive process that is more or less cyclical (such as climatic and sea-level changes induced by orbital cycles). A depositional sequence may be created by a sea-level cycle but also by other processes (see Chapter 2.2.1), and a symmetrical sea-level cycle may create an asymmetrical depositional sequence (Chapter 2.2.2).

Unconformities created by absence of sediment accumulation on the sea floor (e.g., current-induced bypass) or by submarine or subaerial erosion will form boundaries that may be recognized in the field and delimit "beds". The same holds for rapid changes in facies where especially clay input creates 
well-defined bedding planes. Such boundaries, however, may be obliterated by bioturbation as long as the sediment stays soft and the bottom waters are oxygenated. During early diagenesis, diagenetic fronts may also create bedding planes that are recognizable in the field (e.g., Westphal et al., 2004). Stacking of beds means that there were repetitive environmental changes through time, and the analysis of the facies evolution within the beds and of the bedding surfaces allows determining which processes were active. However, a bed as seen in the outcrop does not necessarily correspond to a depositional sequence as defined above.

On a shallow carbonate platform, sea-level changes are an important factor because they control water depth and accommodation potential. A second important parameter is rainfall in the hinterland that delivers clays and other terrigenous material (e.g., quartz, organic matter) to the marine realm. Depending on the energy regime and the morphology of the platform, the clays may be reworked and winnowed by currents and waves, or they are ponded in depressions (Fig. 2). If sea-level changes and terrigenous input are associated with orbitally controlled climate changes and the clays create bedding surfaces, the repetitive stacking of beds may indeed be interpreted in terms of cyclostratigraphy. However, the terrigenous input may be in-phase or out-of-phase with sea-level changes, or it may be independent of sea level (Strasser and Hillgärtner, 1998). For example, during one sea-level cycle, one depositional sequence is created that shows first a deepening-up then a shallowing-up facies evolution. If there are two or more episodes of rainfall in the hinterland during the same time interval, the clays being washed into the system will lead to the formation of two or
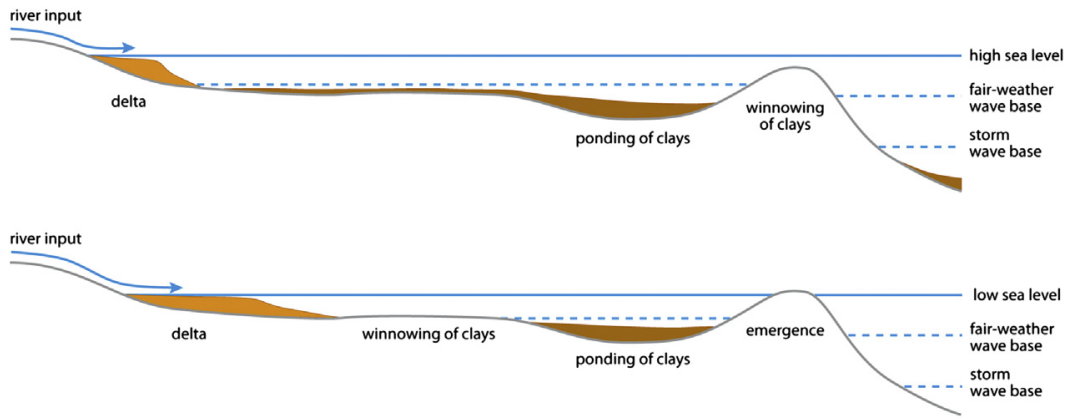

Figure 2 Clay input and distribution as a function of sea level (high versus low), wave base, and platform morphology. The amount of clays is a function of river input (and thus climate in the hinterland), which can vary in tune with sea-level changes, or independently. 
more beds within the one depositional sequence. The interpretation of clay seams or marly layers separating carbonate beds therefore has to be carefully evaluated.

\subsubsection{Allocyclic versus Autocyclic and Random Processes}

Processes that are repetitive (cyclical) and controlled by factors external to the sedimentary basin are called "allocyclic". Examples are eustatic sea-level changes and climate changes that act over the entire carbonate platform and beyond. In contrast, "autocyclic" processes are inherent to the sedimentary system and create facies repetitions independently of external factors. For example, lateral migration of shoals may lead to several, superimposed shallowing-up units at constant sea level (Pratt and James, 1986). Another possibility is the progradation of a tidal flat, which fills in the lagoon and thus stops the carbonate production that feeds the same tidal flat: a shallowingup sequence has been created. Once subsidence has allowed a new lagoon to form, a new tidal flat will prograde again to create a second sequence (Ginsburg, 1971).

Many shallow carbonate platforms display facies mosaics (e.g., Rankey and Reeder, 2010; Adomat and Gischler, 2015). These may follow substrate morphology or structural elements such as fault lines but may also have a random or self-organized distribution (e.g., Burgess and Wright, 2003; Burgess, 2006). Facies evolution through time thus is difficult to predict as no regular pattern of facies successions can be established (Fig. 3). For example, at rising sea level, an aggrading or even shallowing-up sequence can form contemporaneously to a deepening-up one, on the same platform, if carbonate accumulation keeps up with or outpaces sea-level rise (Fig. 3C). Based on computer simulations, Dexter et al. (2009) stated that stochastic processes could mask an orbitally controlled sea-level signal in the sedimentary record.

If the amplitude of the allocyclic processes is high enough, the autocyclic or random ones will be overprinted. For example, a significant drop in eustatic sea level will subaerially expose the entire platform and create a karst surface; if such drops are repeated, a record of stacked beds with clearly defined boundaries will develop. Repetitive periods of heavy rainfall in the hinterland will flush clays onto the entire platform and create discrete bedding surfaces, independent of the possibly random facies evolution within these beds. 

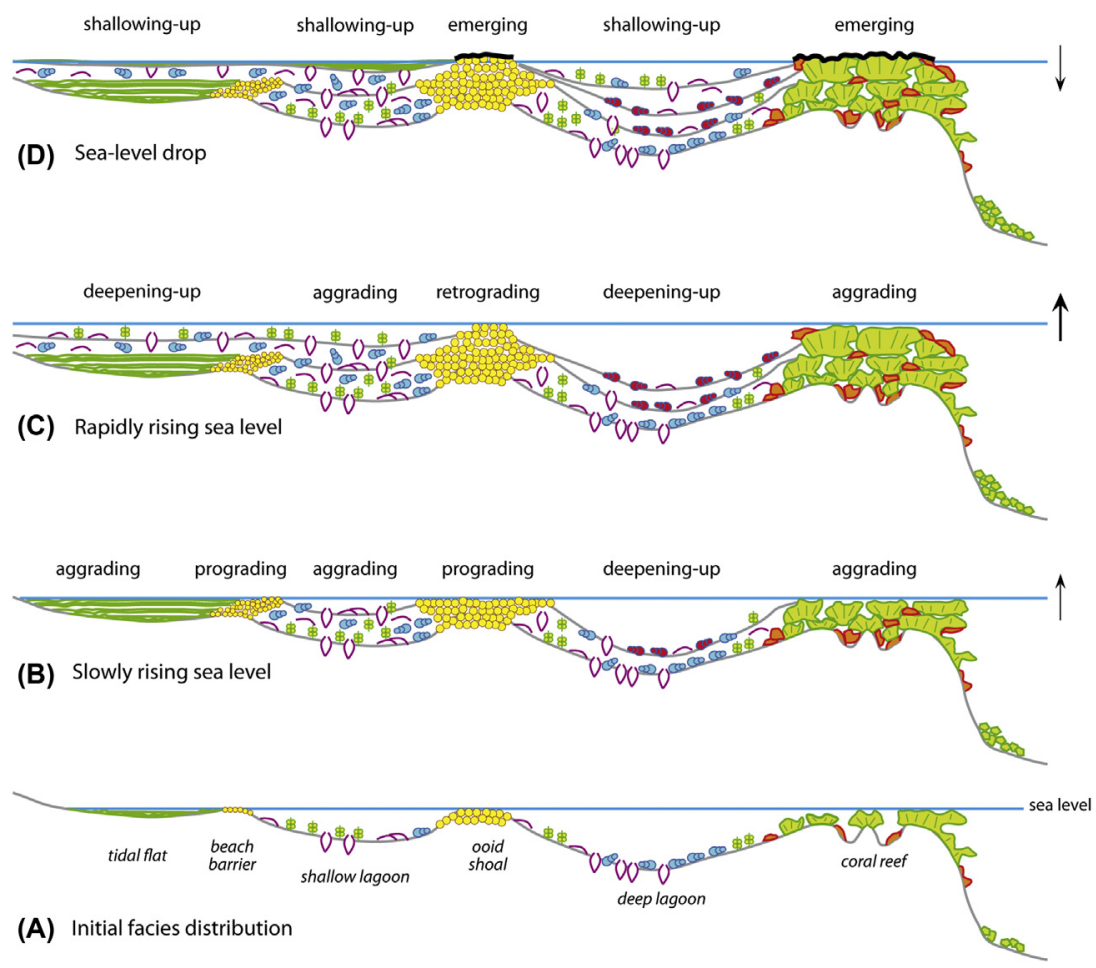

Figure 3 Sketch of possible facies evolution of different, juxtaposed environments during slow then rapid sea-level rise $(A, B, C)$, and finally during a sea-level drop (D). Note that the resulting vertical depositional sequences may display aggrading, prograding, and deepening-up trends at the same time, depending on their position on the platform and on the potential of carbonate production and accumulation.

\subsubsection{Long-Term versus Short-Term Processes}

Orbitally-induced environmental changes act on periodicities of a few tens to a few hundreds of thousands of years (Milankovitch frequency band) as a function of the orbital parameters (Berger et al., 1989; Laskar et al., 2011):

- precession cycle with an average of 20 kyr today but somewhat shorter in the past;

- obliquity cycle with a major peak at $41 \mathrm{kyr}$ today but much shorter in the past;

- short and long eccentricity cycles (100 and 405 kyr, respectively), stable throughout Earth history; 
- the longer periodicities (1.2 and 2.4 Myr; Hilgen et al., 2003) are not considered here because their impact often is difficult to distinguish from the long-term tectonic and eustatic processes affecting a carbonate platform.

The high-frequency cycles (20 to $405 \mathrm{kyr}$ ) are superimposed on millionyear scale eustatic changes in sea level induced by mid-ocean-ridge activities, water exchange with the mantle, intraplate deformation, or changes in large-scale sediment input into the ocean basins (e.g., Cloetingh, 1986; Conrad, 2013; Haq, 2014). A long-term sea-level rise will generally create more accommodation on the platform and attenuate short-term sea-level falls, while a long-term sea-level fall will lead to more subaerial exposure (Fig. 4).

The second factor controlling accommodation is subsidence. On passive margins where many carbonate platforms are hosted, subsidence rate generally is low (a few cm/kyr; e.g., Grotzinger, 1986; Husinec and Jelaska, 2006) but may be irregular due to block-faulting (e.g., Wildi et al., 1989). Subsidence mainly acts on the long-term history of a carbonate platform. However, Cisne (1986) and Bosence et al. (2009) have proposed that high-frequency changes in subsidence rate may create stacking patterns of beds similar to those formed under the influence of cyclical sea-level changes.

In Fig. 4, the sedimentary record at one point on the shallow platform resulting from 5 sea-level cycles is simulated. For simplification, the cycles are assumed to be symmetrical as it would be the case in a greenhouse world where insolation changes are more or less directly translated into sea-level changes (e.g., Read et al., 1995), in contrast to the highamplitude asymmetrical cycles typical for icehouse worlds where there is a slow build-up of polar ice and a fast melting (e.g., Shackleton, 1987). Amplitudes are variable, reflecting the variability of insolation intensity of 5 precession cycles modulated by a short eccentricity cycle (Berger, 1990). The sea-level amplitudes are on the order of one to several meters, as inferred from the typical meter-scale beds in the sedimentary record (see Chapter 3). Subsidence is considered to be constant. The sedimentary record is interpreted in terms of sequence stratigraphy (Fig. 4A), where sequence boundaries form during loss of accommodation, transgressive surfaces at the beginning of creation of new accommodation, and maximum-flooding surfaces or maximum-flooding intervals during the fastest increase in accommodation (Vail et al., 1991; Montañez and Osleger, 1993). Sedimentation rate is variable: slow after subaerial 

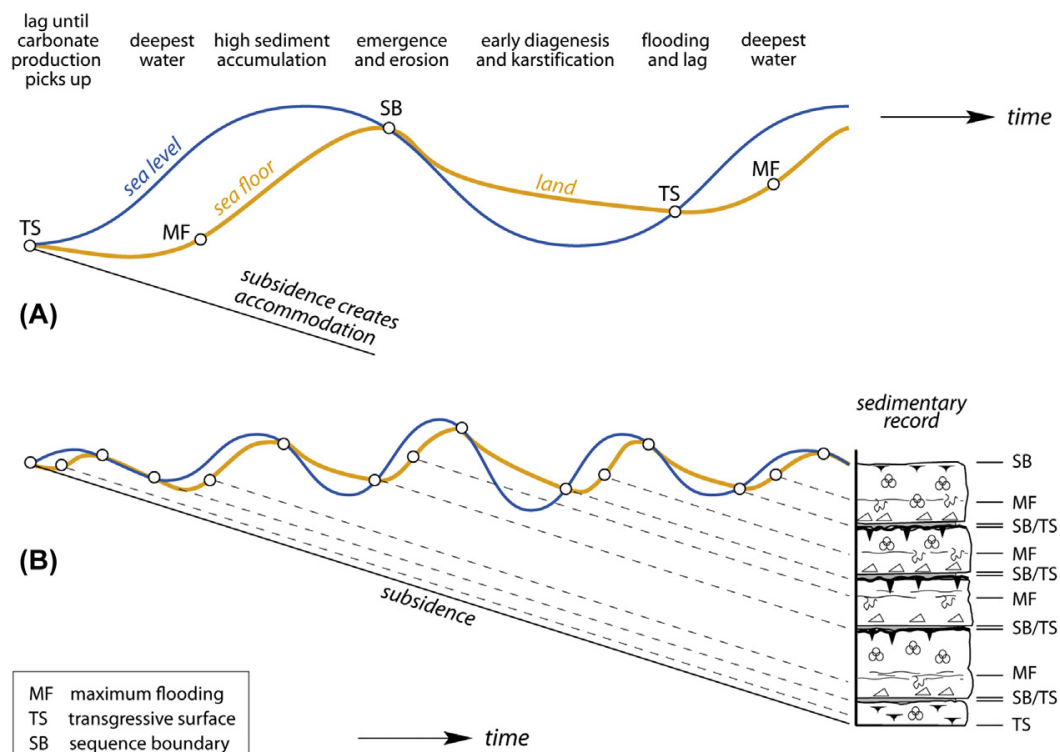

$\begin{array}{ll}\text { SB } & \text { sequence boundary } \\ \text { is bioturbation } \\ & \text { birdseyes } \\ \triangle & \text { lithoclasts } \\ \infty & \text { benthic fossils } \\ \tau & \text { karst }\end{array}$

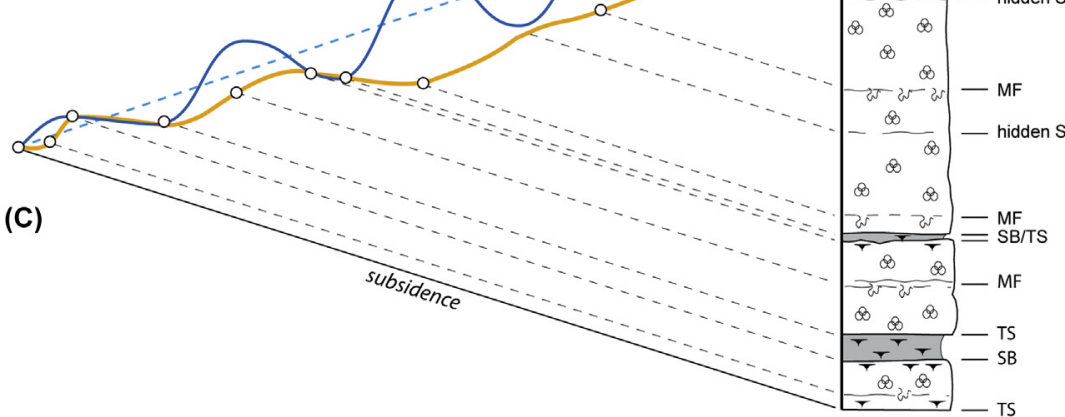

Figure 4 Hypothetical sedimentary record created by high-frequency sea-level fluctuations (amplitudes are assumed to be meter-scale). (A) Relation between sea level and sediment surface, and positions of sequence boundaries, transgressive surfaces, and maximum-flooding intervals. (B) Sedimentary record created by 5 sea-level cycles with varying amplitudes, no long-term trend. (C) Sedimentary record resulting from the same high-frequency fluctuations superimposed on a long-term rising trend of sea level. Sedimentary columns without compaction. For more explanation refer to text. 
emergence when the carbonate-producing organisms first have to recolonize the exposure surface (lag time: Tipper, 1997; Kemp and Sadler, 2014), high when the ecological conditions are optimal, and slow again when the water is not deep enough to permit healthy carbonate production. It has to be kept in mind, however, that this simulation concerns only one point on the platform, and that sedimentation rates may vary significantly from one place to the other (Fig. 3). Once sea level drops below the sediment surface, some erosion of loose material may occur before early diagenesis stabilizes the sediment and chemical erosion (karstification) predominates.

In Fig. 4B, long-term accommodation is created only by subsidence. It shows that sequence boundaries related to low-amplitude sea-level cycles are characterized by tidal flats (visualized here by the birdseye symbol), whereas high-amplitude fluctuations lead to development of karst surfaces. If the same high-frequency sea-level curve is superimposed on a long-term rising sea-level trend (Fig. 4C), the resulting accommodation is much greater. Starting from zero, the first two sequences still have a tidal flat at their boundaries, but subsequent, even high-amplitude sea-level drops do not generate subaerial exposure surfaces to create a well-visible sequence boundary. Only a facies change (from deeper to shallower facies and back) allows the identification of the lowest accommodation ("hidden sequence boundary" in Fig. 4C; "subtidal cycles" of Osleger, 1991). If no facies change is discernible, then the sea-level cycle is not recorded at all.

High-frequency fluctuations in accommodation have often been reconstructed by using "Fischer plots" (Fischer, 1964; Read and Goldhammer, 1988; Sadler, 1994; Husinec et al., 2008) whereby the thickness of each unit (with a deepening-shallowing facies trend, and/or delimited by distinctive surfaces) is plotted against time. By this, long-term trends in accommodation change can be detected. However, such reconstructions are only valid as sea-level proxies if each unit shallows upwards into the intertidal zone (i.e., up to zero water depth), if there is no erosion, if subsidence rate is constant, and if each unit represents the same time duration. Unfortunately, these conditions are only rarely fulfilled.

If accommodation is not completely filled by sediment and the beds represent subtidal cycles (Osleger, 1991), estimation of water depth based on facies is very difficult (Immenhauser, 2009; Purkis et al., 2015). The evolution of unit thicknesses through time thus gives information about carbonate production potential and accommodation but cannot be used as an equivalent of sea-level changes. 


\subsubsection{Fragmentary Sedimentary Record}

Orbitally-controlled climate and/or sea-level changes are only fully recorded if the conditions are ideal:

- enough accommodation (as a function of subsidence and eustatic sea level) to avoid prolonged subaerial exposure and erosion;

- high sedimentation rate to avoid condensation;

- absence of high-energy events that destroy previous sedimentary deposits. On shallow carbonate platforms, these conditions are only rarely fulfilled, and hiatuses and condensation are common phenomena (e.g., Sadler, 1994; Strasser, 2015; Husinec and Read, 2018). For example, if a long-term sea-level drop combines with a slow subsidence rate, even high amplitudes of high-frequency sea-level changes may not be enough to create a sedimentary record on the platform. Cycles that are not recorded on emerged platforms were called "missed beats" by Goldhammer et al. (1990). During an individual sea-level cycle, only part of the history is recorded if sea-level fall outpaces subsidence, thus leading to loss of accommodation (Fig. 4A). Currents and waves may constantly rework the sediment, and the record of high-frequency changes is lost. If sediment accumulation is low, bioturbation may destroy any originally cyclic sedimentation. If the orbital signal (and its translation into climate and/or sea-level changes) is weak, it may be recorded in one depositional environment that is sensitive enough but not in a different one. On tidal flats, even a sea-level change of only a few tens of centimeters will induce important changes in the distribution of tidal channels and microbial mats. In a shallow lagoon, a drop in wave base following a drop in sea level will induce winnowing on the sea floor, while the same drop will not affect a deeper lagoon. It may thus be difficult to correlate depositional sequences from one environment to another.

\subsection{The Latemar Controversy}

From the above it is clear that the estimation of the time involved in the cyclical stacking of facies and beds on shallow carbonate platforms is not an easy task (e.g., Eberli, 2013). A good example of the difficulties encountered is the controversy about the Middle Triassic Latemar platform in northern Italy (Zühlke, 2004; Meyers, 2008). The individual, meter-scale beds display a shallowing-up facies evolution, implying that they formed driven by sea-level changes. The hierarchical stacking (5 beds commonly form a bundle) and time-series analysis suggest that there was an orbital control ( 5 precession cycles within one short eccentricity 
cycle), implying that the cyclic series had a duration of 9 to $12 \mathrm{Myr}$ (e.g., Goldhammer et al., 1990; Satterley, 1996; Preto et al., 2004). In contrast, ammonite biostratigraphy calibrated by $\mathrm{U}-\mathrm{Pb}$ ages measured in volcanic ash layers suggests a duration of 2 to $4 \mathrm{Myr}$ for the same interval (e.g., Brack et al., 1996; Mundil et al., 1996). This would mean that one bed does not correspond to the precession cycle of $20 \mathrm{kyr}$ but must have formed in tune with a higher-frequency cyclical process with periodicities of $4.2 \mathrm{kyr}$ ("sub-Milankovitch" cycles; Zühlke et al., 2003; Zühlke, 2004). The modelling by Forkner et al. (2010, p. 1) produced "Latemar-like stratigraphy with both pure Milankovitchian and mixed Milankovitchian-sub-Milankovitchian temporal frameworks". Based on magnetostratigraphy, Kent et al. (2004) and Spahn et al. (2013) found that the cyclical stacking was controlled by sea-level changes with periodicities of about $1.7 \mathrm{kyr}$.

During the Quaternary, cyclicities of a few kyr duration are related to ice-sheet dynamics and oceanic circulation patterns (Dansgaard-Oeschger cycles, Heinrich events, Bond cycles; e.g., Romero et al., 2011; Saha, 2015). Rodrigo-Gamiz et al. (2014, p. 78), analysing sediments of the last $20 \mathrm{kyr}$ in the western Mediterranean, found periodicities of 1.3, 1.5, 2, and $5 \mathrm{kyr}$ and explained these by "climate cycles ... coupled with oceanatmosphere fluctuations". Concerning the Latemar platform, Zühlke (2004, p. 206) wrote: "it is well possible that rapid oceanographic and/or atmospheric changes triggered a strong sub-Milankovitch signal in the Middle Triassic". Sub-Milankovitch periodicities are also seen in ancient deeper-water sections. For example, Rodríguez-Tovar and Pardo-Igúzquiza (2003) detected a 13 to 14-kyr peak in the Kimmeridgian of southern Spain, and De Winter et al. (2014) found a prominent 7-kyr cycle expressed in the Campanian of DSDP Site 516F in the South Atlantic.

\section{CASE STUDY: OXFORDIAN OF THE SWISS JURA}

In order to show the caveats and limitations when applying the cyclostratigraphic approach to shallow-marine carbonates but also to demonstrate its potential to better interpret the sedimentary record, a case study of the Oxfordian (Late Jurassic) in the Swiss Jura Mountains is presented.

\subsection{Geological and Stratigraphic Context}

During the Oxfordian, the Swiss Jura Mountains were part of a shallow carbonate platform situated at a paleolatitude of 26 to $27^{\circ} \mathrm{N}$, north of 


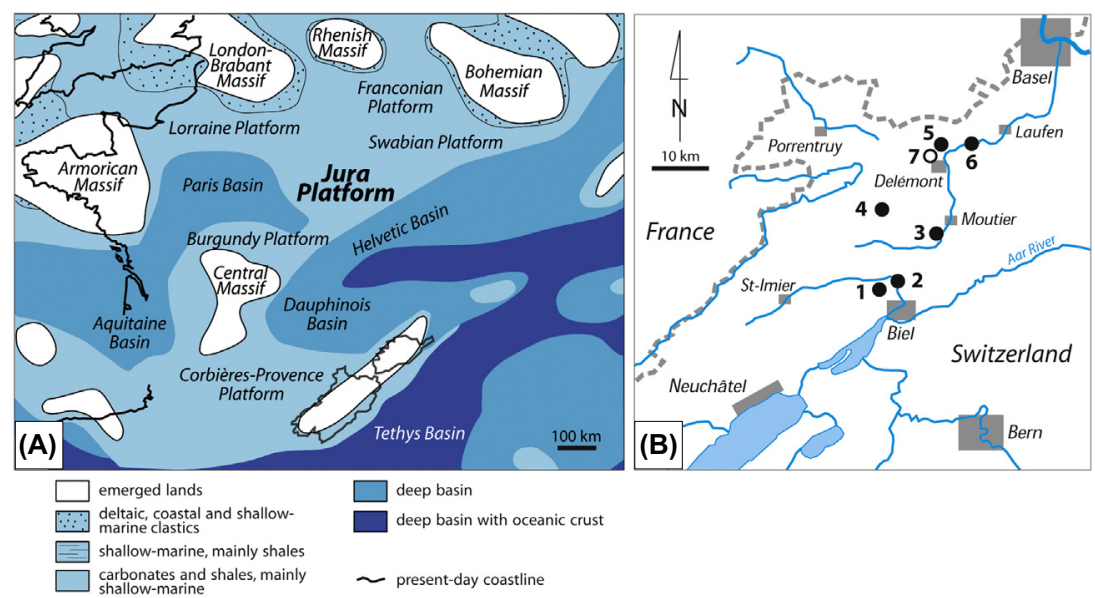

Figure 5 (A) Paleogeographic setting of the Jura platform during the Oxfordian. Modified from Carpentier et al. (2006), based on Enay et al. (1980), Ziegler (1990), and Thierry et al. (2000). (B) Locations of the studied sections in the Jura Mountains of northwestern Switzerland. 1: Forêt de Châtel; 2: Péry-Reuchenette; 3: Gorges de Court; 4: Pichoux; 5: Mettemberg-Soyhières; 6: Liesberg; 7: Vorbourg. In blue (or grey): lakes and rivers.

the Tethys Ocean (Fig. 5A; Dercourt et al., 1993). The platform was structured by synsedimentary faults related to the reactivation of basement faults (Allenbach, 2001). The lithostratigraphy and the ammonite biostratigraphy have been established by Gygi (1995, 2000), and a sequence-stratigraphic interpretation was first proposed by Gygi et al. (1998). For the purpose of this case study, the focus will be on six sections (Fig. 5B) that cover the interval between sequence boundaries $\mathrm{Ox} 7$ and $\mathrm{Ox} 8$ (Fig. 6). These sequence boundaries are labelled according to Hardenbol et al. (1998) and Gygi et al. (1998). The Vorbourg section (number 7 in Fig. 5B) offers an example of detailed analysis of an elementary sequence corresponding to the precession cycle (see Chapter 4).

\subsection{Facies Evolution}

The section of Gorges de Court, logged in detail by Strasser et al. (2000) and Hug (2003), demonstrates the evolution of depositional environments through time (Fig. 7). The Hauptmumienbank Member is characterised by abundant oncoids but also contains ooids, echinoderms and corals, implying normal-marine shallow-water conditions. The Oolithe rousse Member is rich in quartz sand and plant fragments; its reddish ("rousse") color stems from iron oxides. While the environment still was shallow-marine, a more humid 


\begin{tabular}{|c|c|c|c|c|c|}
\hline \multirow{2}{*}{\multicolumn{2}{|c|}{$\begin{array}{l}\text { Chrono- } \\
\text { strat. }\end{array}$}} & \multirow{2}{*}{$\begin{array}{l}\text { Biostratigraphy } \\
\text { ammonite zones }\end{array}$} & \multirow{2}{*}{$\begin{array}{l}\text { Sequence } \\
\text { boundaries }\end{array}$} & \multicolumn{2}{|c|}{ Lithostratigraphy } \\
\hline & & & & formations & members \\
\hline \multirow{5}{*}{ 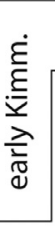 } & & Hypselocyclum & Kim 2 & & \\
\hline & & Platynota & $\operatorname{Kim} 1$ & Reuchenette & \\
\hline & \multirow{5}{*}{ 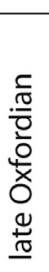 } & Planula & \multirow{3}{*}{$0 \times 8$} & Balsthal & Verena \\
\hline & & \multirow{2}{*}{ Bimammatum } & & Courgenay & La May \\
\hline & & & & \multirow{3}{*}{ Vellerat } & Oolithe rousse \\
\hline & & Hypselum & \multirow{2}{*}{$\begin{array}{l}0 \times 7 \\
0 \times 6\end{array}$} & & Hauptmumienbank \\
\hline & & Bifurcatus & & & Röschenz \\
\hline
\end{tabular}

Figure 6 Stratigraphic context of the studied sections. Chrono- and biostratigraphy following Wierzbowski et al. (2016). The Oxfordian-Kimmeridgian boundary in the Tethyan realm was first placed at the Planula-Platynota boundary but is now proposed to be situated at the limit between the Hypselum and Bimammatum ammonite zones. Sequence stratigraphy according to Hardenbol et al. (1998) and Gygi et al. (1998); lithostratigraphy according to Gygi (1995).

climate furnished terrigenous material from the emerged lands to the north (Fig. 5A). The overlying La May Member starts with an ooid grainstone, then contains more oncoids and corals. The depositional environment was mainly that of protected, bioturbated lagoons with patch reefs. However, many bed tops are dolomitized (clear-rim-cloudy-center displacive crystals; Hug, 2003), suggesting a more arid climate and the development of sabkhas. The member ends with a dolomitized tidal flat overlain by a layer of coal, indicating a rapid change from a more arid to a more humid climate. The overlying Verena Member is composed of ooid- and peloid-rich grainstones with brachiopods and echinoderms, indicating a fully marine high-energy environment.

The sedimentary record is well structured into individual beds (Fig. 7), the boundaries of which are marked by clay seams.

\subsection{Sequence- and Cyclostratigraphic Interpretation}

The sequence- and cyclostratigraphic interpretation and the correlation of the six studied sections (Fig. 8) are based on the concepts presented in Strasser et al. (1999); the sequence-stratigraphic nomenclature is that of Vail et al. (1991). Elementary sequences are defined as the smallest units in which facies trends indicate a cycle of environmental change, including sea-level change. When no facies change occurs within a bed, the clay seams at the bed limits indicate that there was terrigenous input from the 


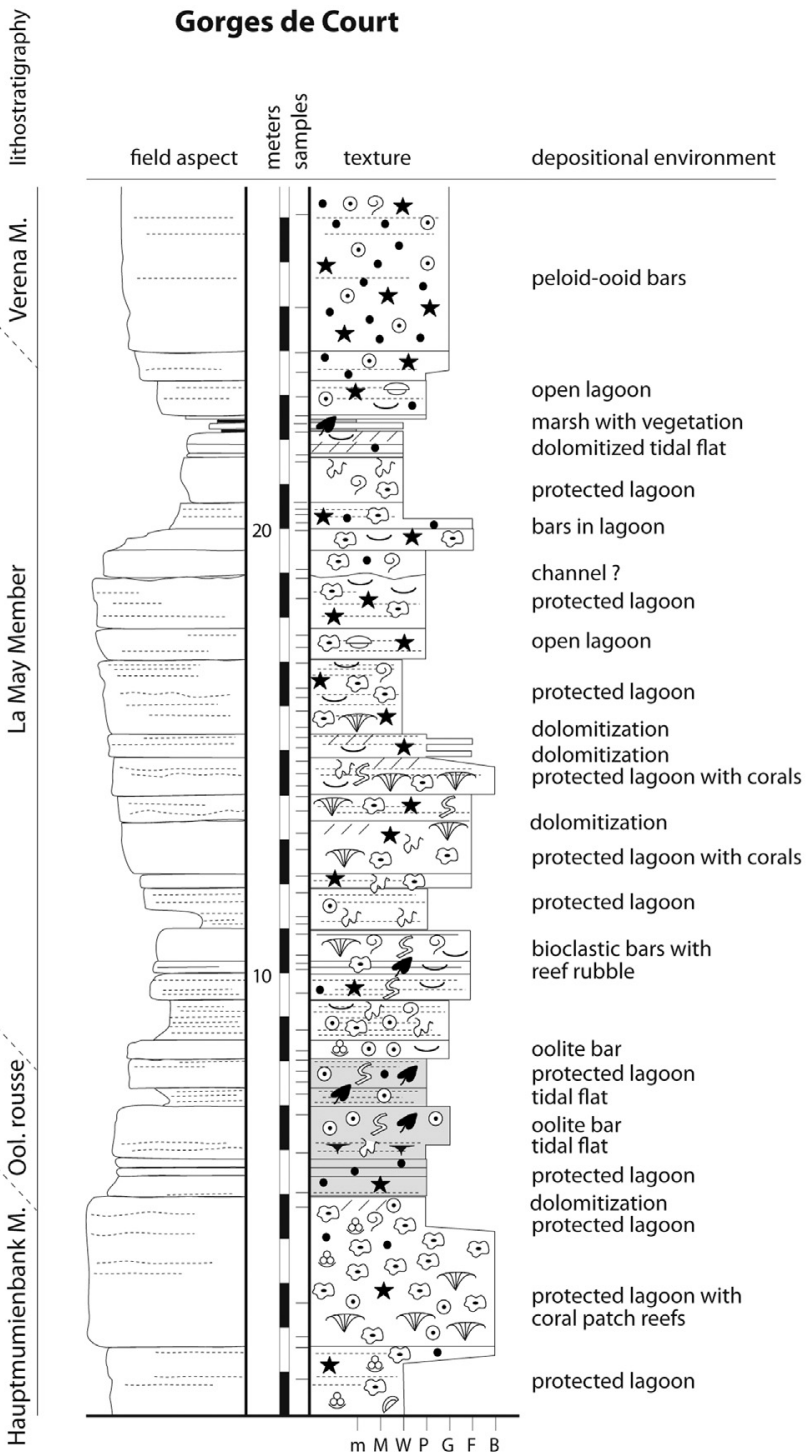

\begin{tabular}{|c|c|}
\hline \multicolumn{2}{|c|}{ Facies } \\
\hline & peloids \\
\hline$\Leftrightarrow$ & oncoids \\
\hline$\odot$ & ooids \\
\hline$\ominus$ & brachiopods \\
\hline$\star$ & echinoderms \\
\hline 8 & foraminifera \\
\hline $\mathbb{D}$ & corals \\
\hline & bivalves \\
\hline ? & gastropods \\
\hline$\theta$ & ostracodes \\
\hline$S$ & serpulids \\
\hline 9 & plant fragments \\
\hline$T$ & birdseyes \\
\hline W & bioturbation \\
\hline & lamination \\
\hline 1,1 & dolomitization \\
\hline$\wedge$ & evaporites \\
\hline & quartz sand \\
\hline
\end{tabular}

\begin{tabular}{|ll|}
\hline \multicolumn{2}{|l|}{ Texture } \\
m & marl \\
M & mudstone \\
W & wackestone \\
P & packstone \\
G & grainstone \\
F & floatstone \\
B & boundstone \\
\hline
\end{tabular}

Figure 7 Detail of the Gorges de Court section (number 3 in Fig. 5B). Log, facies analysis and interpretation of depositional environments following Strasser et al. (2000) and Hug (2003).

hinterland (Figs. 2 and 5A; Strasser and Hillgärtner, 1998). Small-scale sequences are composed of 2 to 7 elementary sequences and generally display a deepening then shallowing trend, with the shallowest facies at the boundaries. Four small-scale sequences compose a medium-scale 


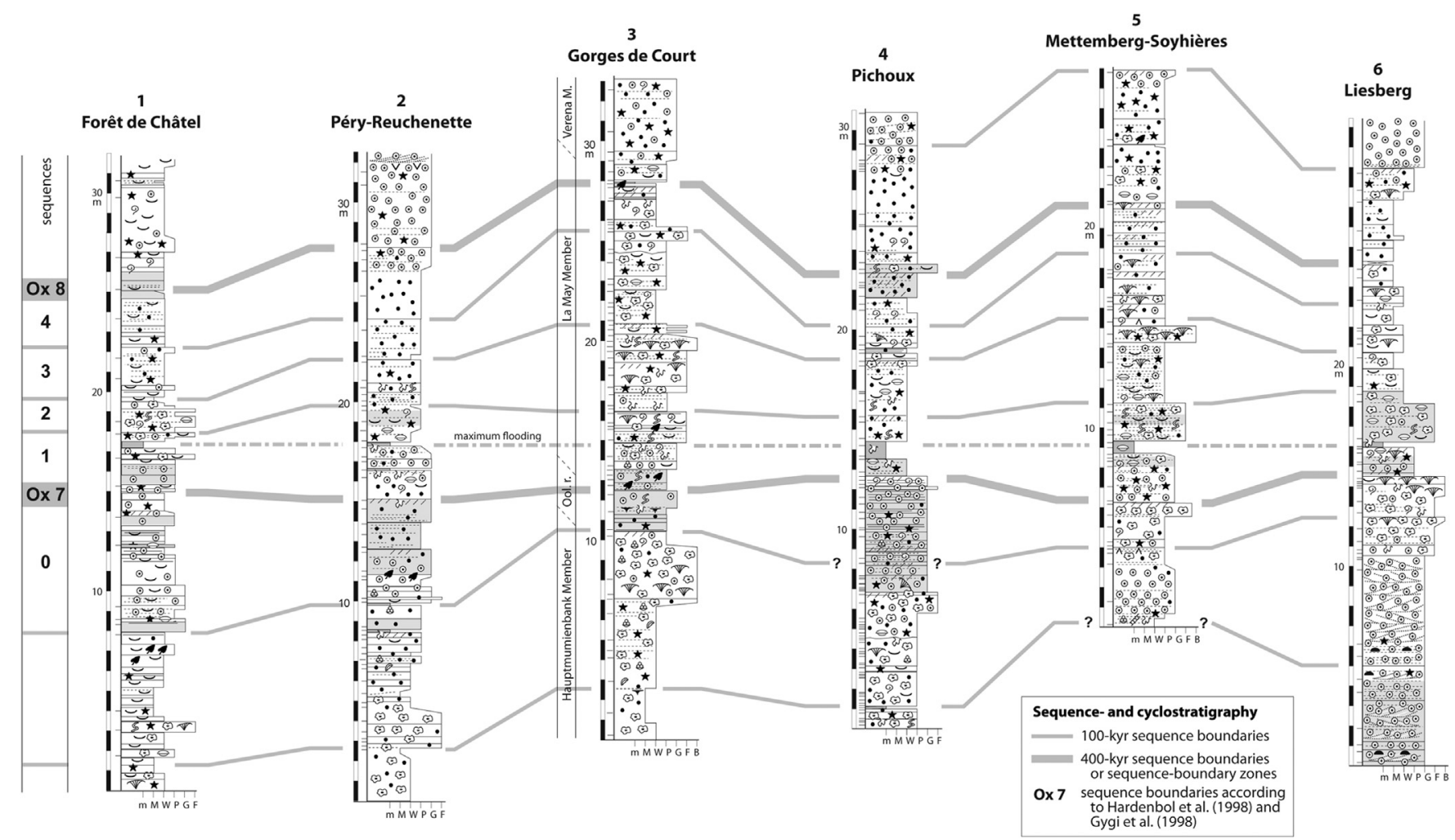

Figure 8 Sequence- and cyclostratigraphic correlation of selected Oxfordian sections, concentrating on the interval between sequence boundaries Ox 7 and Ox 8 (see Fig. 6). The geographic position of the sections is shown in Fig. 5B. The log of Forêt de Châtel after Gsponer (1999), Péry-Reuchenette, Mettemberg-Soyhières and Liesberg after Hug (2003), Gorges de Court after Strasser et al. (2000) and Hug (2003), Pichoux after Pittet (1996). Symbols are explained in Fig. 7. For discussion refer to text. 
sequence, which again displays a general deeping-shallowing trend of facies evolution and the relatively shallowest facies at its boundaries. In the case presented here, the sequence defined by the boundaries $\mathrm{Ox} 7$ and $\mathrm{Ox} 8$ represents a medium-scale sequence (Strasser et al., 2000). The relatively deepest and/or most open-marine facies of this sequence formed at the time of maximum flooding (taken as datum in Fig. 8). If several elementary sequences compose an interval of shallowest or deepest facies, a sequenceboundary zone respectively a maximum-flooding interval is defined (Montañez and Osleger, 1993). The concept of parasequences bounded by marine flooding surfaces (Van Wagoner et al., 1990) is not applied here because many of the elementary, small-scale, and medium-scale sequences are clearly bounded by surfaces expressing the shallowest depositional environment, and because these sequences can be further subdivided into deepening and shallowing parts. Each section is first interpreted independently, then a best-fit solution is sought for that respects the chronostratigraphic framework and shows the least contradiction in sequenceand cyclostratigraphic interpretation (Fig. 8).

According to Gygi et al. (1998), sequence boundary Ox 7 is situated at the base of the Bimammatum ammonite zone, $\mathrm{Ox} 8$ at the limit between the Bimammatum and Planula zones (Fig. 6). Hardenbol et al. (1998), who established a sequence-stratigraphic framework for European basins, attributed an age of 155.15 Ma to Ox 7 and of 154.63 Ma to Ox 8. These numerical values are interpolations based on the duration of the Oxfordian of about 5.3 Myr, from 159.4 \pm 3.6 to $154.1 \pm 3.2 \mathrm{Ma}$ (Berggren et al., 1995). Gradstein et al. (2012) and the International Chronostratigraphic Chart (2017) indicate a duration of about 6.2 Myr, from $163.5 \pm 1.0$ to $157.3 \pm 1.0 \mathrm{Ma}$. In the Geological Time Scale 2012 (Gradstein et al., 2012, p. 756), the sequence boundaries are indicated only for the Boreal realm: Ox 7 is dated at $158.8, \mathrm{Ox} 8$ at $158.2 \mathrm{Ma}$. Despite these uncertainties related to the Boreal-Tethyan correlation (e.g., Colombié and Rameil, 2007; Wierzbowski et al., 2016), the time interval between sequence boundaries $\mathrm{Ox} 7$ and $\mathrm{Ox} 8$ can be estimated to be in the order of 500 to $600 \mathrm{kyr}$. However, considering the hierarchical stacking (bundling) of 2 to 7 elementary sequences into a small-scale sequence, and of 4 small-scale sequences into a medium-scale one, it can be assumed as a working hypothesis that the medium-scale sequence discussed here corresponds to the 405-kyr long eccentricity cycle. In fact, it has been shown that in several cases the "third-order" sequences of classical sequence stratigraphy (e.g., Vail et al., 1991) actually formed in tune with the long eccentricity cycle 
or multiples thereof (e.g., Strasser et al., 2000; Gale et al., 2002; Boulila et al., 2008, 2010, 2011; Ogg et al., 2010). Consequently, the small-scale sequences would represent the 100-kyr short eccentricity cycle. The elementary sequences often are difficult or impossible to correlate. They may correspond to the 20-kyr precession cycle, or else they formed through autocyclic processes (see Chapter 2.2.1). The obliquity cycle did not leave any clear signal on the Jura platform that could be interpreted in terms of sea-level variations (Pittet, 1996).

The correlation presented in Fig. 8 shows significant facies variability, vertically as well as horizontally along the time lines given by the cyclostratigraphic interpretation. From this, Strasser et al. (2015) reconstructed facies mosaics for different time slices and monitored the lateral migration of sediment bodies.

\subsection{Reconstruction of Orbitally Controlled Sea-Level Changes}

In order to reconstruct high- and low-frequency sea-level changes that controlled carbonate production and deposition on an ancient shallowmarine platform, several conditions have to be fulfilled:

- the sedimentary record has to be decompacted according to facies, in order to estimate the sediment thickness accumulated during a certain time interval prior to burial;

- the water depth has to be estimated for each facies;

- erosion of previously deposited sediment has to be minimal;

- the time steps have to be as short as possible in order to obtain a curve of highest-frequency sea-level changes.

Two sections are chosen to attempt such a reconstruction: Gorges de Court and Mettemberg-Soyhières, where the well-structured sedimentary record allows for a relatively straightforward cyclostratigraphic interpretation. The smallest stratigraphic units are the elementary sequences that for these two sections are interpreted to have formed in tune with the orbital precession cycle of $20 \mathrm{kyr}$. The methodology follows that developed by Pittet (1994) for the Oxfordian and by Hillgärtner and Strasser (2003) for the Berriasian and Valanginian of the Jura Mountains.

\subsubsection{Compaction and Decompaction}

According to Moore (1989), mechanical reorganization of grains and dewatering in carbonate mud leads to a porosity loss of $10 \%$ to $30 \%$ after the first $100 \mathrm{~m}$ of burial. Shinn and Robbin (1983) showed in experiments 
that mechanical and dewatering compaction leads to a $20 \%$ to $70 \%$ loss of volume. However, these values are less if the sediment is stabilized by early cementation (Halley and Harris, 1979). Goldhammer (1997) estimated a compaction of slightly over 50\% for carbonate mud buried at $1000 \mathrm{~m}$, and of about 15\% for carbonate sand at the same burial depth. According to Enos (1991), muddy terrigenous and muddy carbonate sediments do not have significantly different compaction rates, but pressure solution along clay seams may enhance chemical compaction in carbonates (Bathurst, 1987). With deeper burial, chemical compaction becomes important. In the Jura Mountains, however, burial was at the most $2000 \mathrm{~m}$ (Trümpy, 1980); nevertheless, pressure solution at grain contacts shows that some compaction must have occurred.

Based on these published values, the Gorges de Court and the Mettemberg-Soyhières sections are decompacted with the following factors (Figs. 9 and 10): 1.2 for grainstones and 2.5 for mudstones. For packstones and wackestones, the intermediate values of 1.5 and 2 are used, for marls the factor 3. Boundstones are thought to have resisted major compaction and a factor of 1.2 is applied. Floatstones with their micritic matrix are treated like packstones.

\subsubsection{Estimation of Water Depth}

On Great Bahama Bank, which is often taken as analogue for ancient carbonate platforms, Harris et al. (2015) found that there is no clear relationship between water depth and facies, and that facies distribution (i.e., muddy versus grainy facies) is rather controlled by currents. They also stated that $60 \%$ of the Bank surface lie in water depths of $5 \mathrm{~m}$ or less. In the studied sections, only tidal flats and bedding surfaces that exhibit penecontemporaneous dolomitization or evaporites can be used as tie points, and a water depth of zero is attributed to them (tidal range is not considered here). For the other facies, the estimation of water depth includes wide error margins. Nevertheless, for the purpose of this case study, the following values are assumed:

Packstones and wackestones with restricted fauna are thought to have formed in protected, shallow bays and are considered to represent about $1 \mathrm{~m}$ water depth. Grainstones often result from winnowing by tidal currents, and also for such facies a water depth of $1 \mathrm{~m}$ is assumed. Packstones and floatstones with abundant fauna are set at $2 \mathrm{~m}$. Coral patch reefs possibly grew up to sea level but are assumed to have needed $2 \mathrm{~m}$ water depth to develop. When an open-marine fauna (e.g., brachiopods) is present, then a water depth of $3 \mathrm{~m}$ is assumed. 


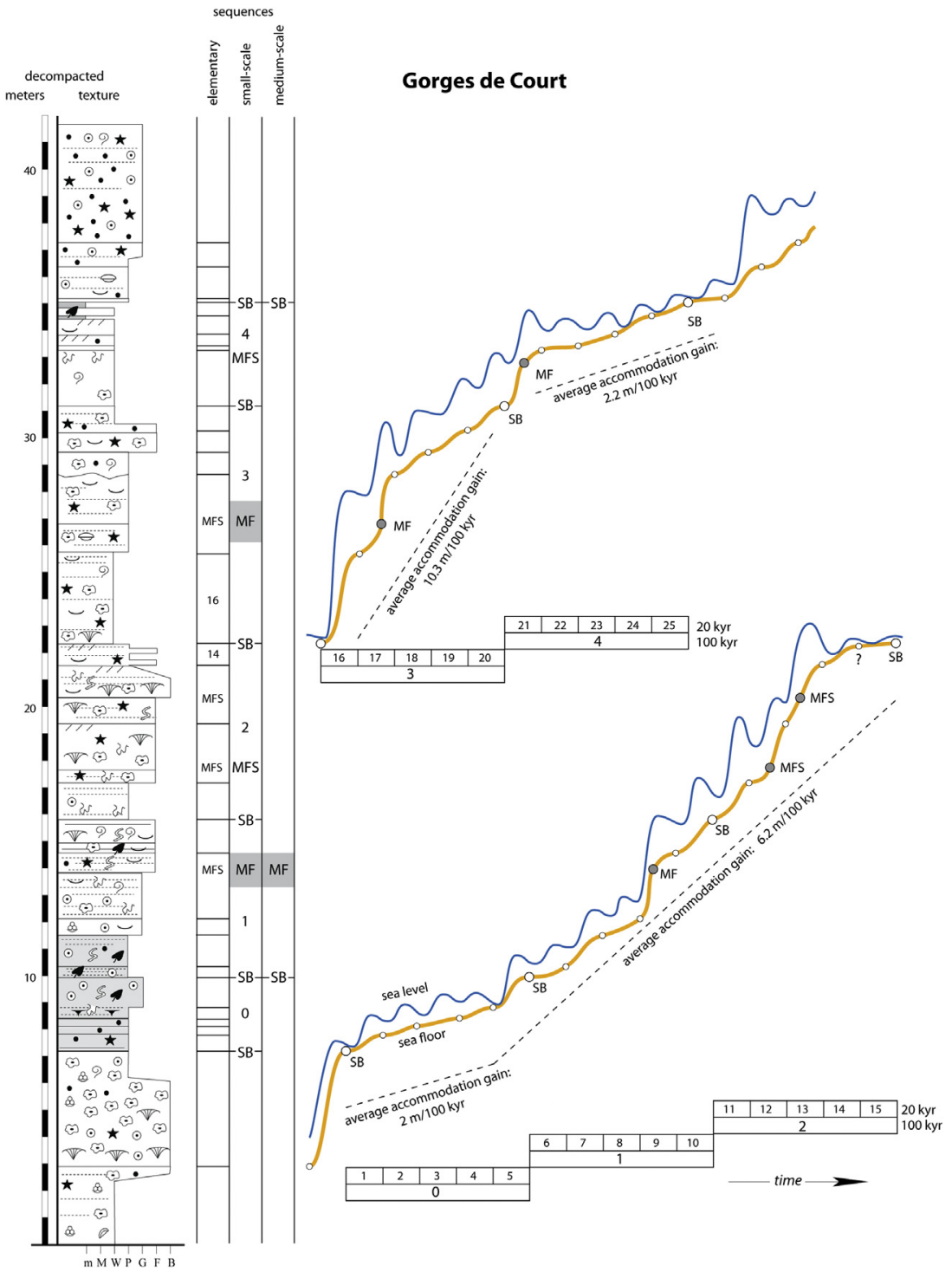

Figure 9 Decompacted section of Gorges de Court (compare with Fig. 7; for decompaction factors see text). Elementary, small-scale, and medium-scale sequences are interpreted following Strasser et al. (2000). SB: sequence boundary; MFS: maximumflooding surface; MF: maximum-flooding interval. Aggradation of the sea floor interpreted for equal time steps of the elementary (20-kyr) sequences. Sea-level curve interpreted according to the water depth in which the different facies formed (see text for explanation). Average accommodation gain (i.e., subsidence + long-term sea-level rise) calculated between tie points where water depth was zero. The sequence boundary at meter 31.2 of the section is not at zero but estimated to have formed at ca. $1.5 \mathrm{~m}$ water depth. 


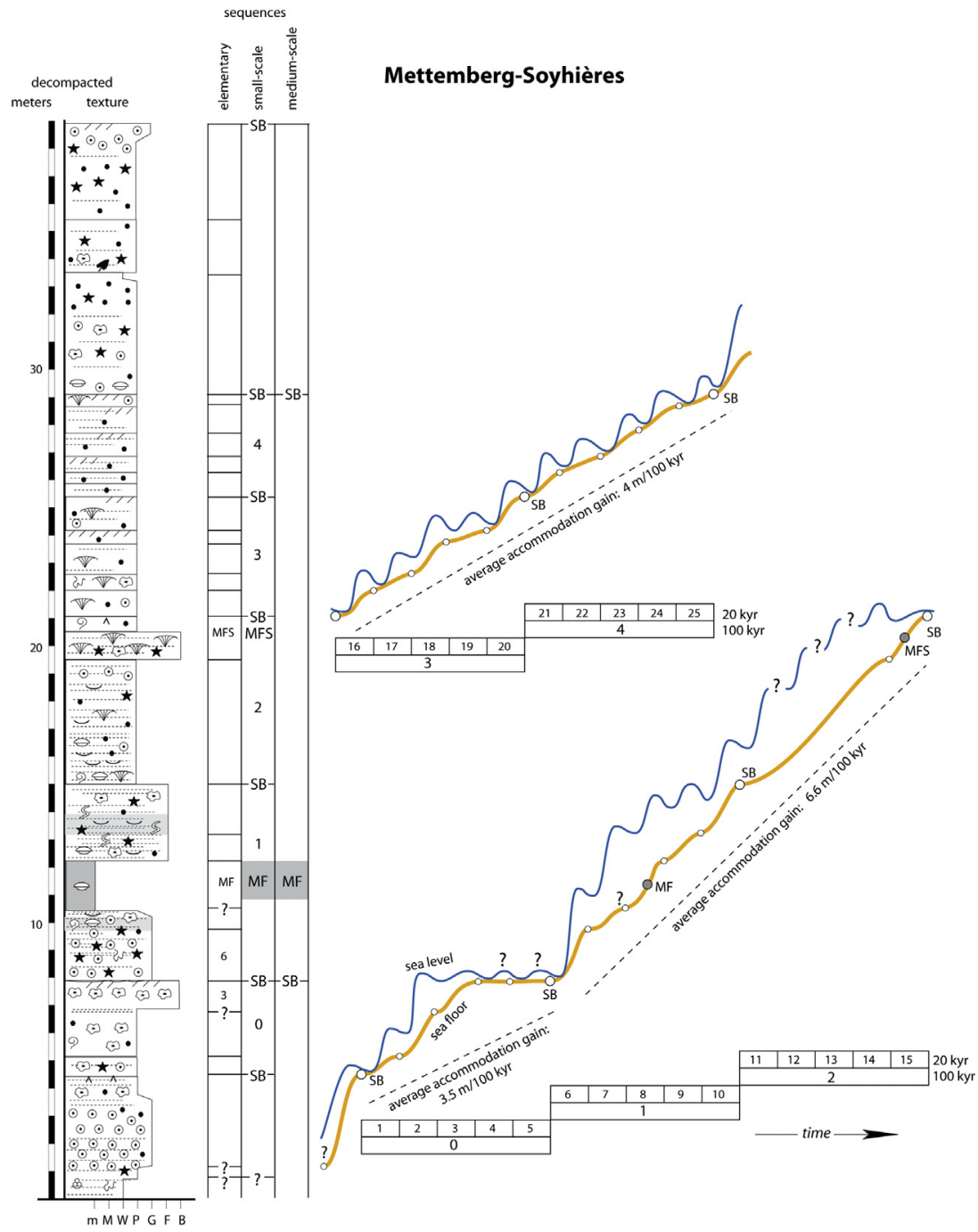

Figure 10 Decompacted section of Mettemberg-Soyhières. For explanation see legend to Fig. 9 and text.

No signs of deep erosion or karstification are visible in the studied sections, with the exception of the irregular surface at meter 19 in Gorges de Court (Fig. 7) that possibly represents a channel floor. This implies that there was a continuous gain in accommodation, which allowed for the recording of most of the sediment produced on the platform. Consequently, the model of Fig. 4C is applied, and the water depth values mentioned above 
correspond to the highest position of sea level. The input of clays to form the bedding surfaces in subtidal facies is assumed to be related to a sea-level drop that exposed the hinterland to increased erosion. This is indicated by the fact that - with the exception of marly maximum-flooding intervals with marine fauna - the marl seams separating the beds are commonly related to the shallowest facies (Pittet and Strasser, 1998b).

\subsubsection{Reconstruction of Accommodation and Sea-Level Changes}

Based on the decompacted sections and the estimated water depths, and within the time frame given by the cyclostratigraphic interpretation, the evolution through time of the sea floor as well as of the sea level can be plotted (Figs. 9 and 10). The time steps are given by the $20 \mathrm{kyr}$ attributed to the elementary sequences. For each of these sequences, the decompacted thickness is added to represent the sea floor, and the estimated water depth for the dominant facies in each sequence is added to approximate the sea level. Furthermore, it is assumed that the sea-level fluctuations were symmetrical (greenhouse conditions; Fig. 4). In the cases where one 100kyr sequence contains less than 5 elementary sequences, it is assumed that the missing ones were not recorded due to low accommodation at a small-scale sequence boundary (elementary sequence 15 at Gorges de Court and elementary sequences 4 and 5 at Mettemberg-Soyhières). Small-scale sequence 2 at Mettemberg-Soyhières does not exhibit well-defined beds but - in comparison with the same sequences at Gorges de Court - it is assumed that it nevertheless spans $100 \mathrm{kyr}$.

An average accommodation gain is visualized by a line that connects two tie points with zero water depth. For the boundary between the 100-kyr sequences 3 and 4 at Gorges de Court, a water depth of $1.5 \mathrm{~m}$ is assumed (Fig. 9).

\subsubsection{Sea-Level Amplitudes and the Orbital Signal}

In a first step, the average accommodation gain is subtracted from the sealevel curves reconstructed for both sections (Fig. 11). This visualizes the high-frequency sea-level changes and reflects in some cases the relation to the 100-kyr cyclicity (cycles 0, 1, and 2 for Mettemberg-Soyhières, cycle 3 for Gorges de Court). However, there are wide discrepancies between the two curves, the most striking one in the first part of 100-kyr cycle 1 (rising trend at Mettemberg-Soyhières versus falling trend at Gorges de Court).

In a second step, only the high-frequency (i.e., 20-kyr) cycles and their amplitudes are considered by subtracting the 100-kyr trends. The 
Sea-level deviation from average accommodation gain

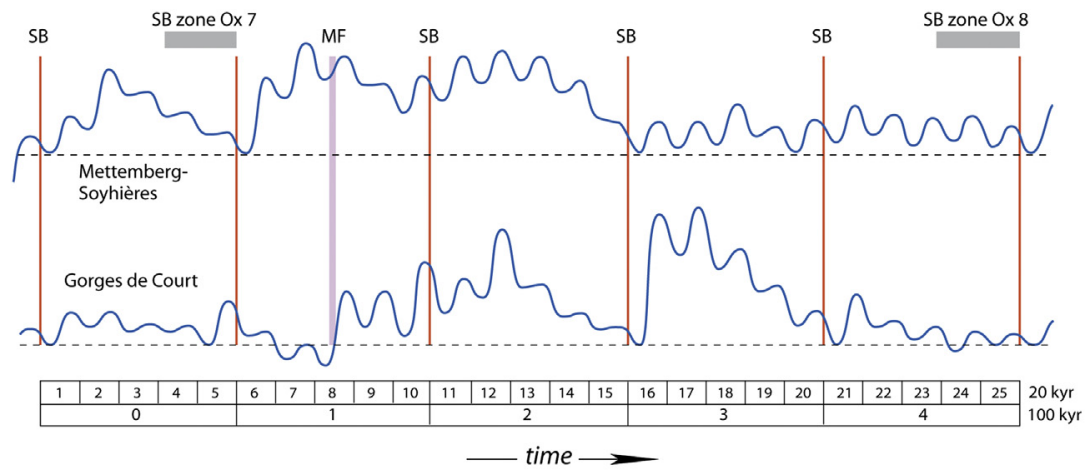

Reconstructed high-frequency sea-level amplitudes

Mettemberg-Soyhières

NaAnAmannari:

Gorges de court

high-amplitude changes in sea level
low-amplitude changes in sea level

Insolation at $30^{\circ} \mathrm{N}$

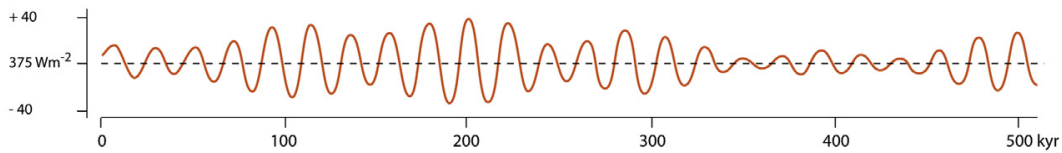

Figure 11 Analysis of the sea-level amplitudes reconstructed from the decompacted sections of Gorges de Court and Mettemberg-Soyhières. In a first step (top of figure) the deviation of sea level from the average accommodation gain is plotted, representing an approximation of high-frequency sea-level change disregarding subsidence and long-term sea-level rise. Sequence boundaries related to the 100-kyr cyclicity are indicated, as are the maximum-flooding interval and the sequence-boundary zones of the 405-kyr cycle. In the lower part of the figure, the amplitudes of the 20-kyr cyclicity are reconstructed by subtracting the 100-kyr trends. Intervals of relatively high and relatively low amplitudes can be identified, comparable to the amplitude changes of insolation at $30^{\circ} \mathrm{N}$ for the last $500 \mathrm{kyr}$ (Berger, 1990). For both Oxfordian sections the sea-level amplitudes increase above SB zone Ox 8 (to the right in the figure), but they cannot be reconstructed because information about the accommodation gain is missing. Note that the amplitudes of insolation also increase at around $500 \mathrm{kyr}$. For more explanation refer to text. 
correspondence between the two sections is better, and intervals of rather high-amplitude changes versus intervals of rather low-amplitude changes can be distinguished. However, there are still discrepancies between the two curves, namely for the 20-kyr cycle 16 (Fig. 11).

The third step concerns the comparison of the reconstructed highfrequency amplitude changes with the curve of insolation changes calculated by Berger (1990) for $30^{\circ} \mathrm{N}$ latitude at the top of the atmosphere, which shows that the amplitudes created by the $20-\mathrm{kyr}$ precession cycle vary significantly through time. The 405-kyr long eccentricity cycle is well defined by the intervals of low amplitude, while the expression of the 100-kyr short eccentricity cycle is more subtle.

\section{DISCUSSION}

Despite the caveats mentioned in Chapter 2, and despite the large error margins inherent in the sea-level reconstructions proposed in Chapter 3, some interesting trends can be distilled from Figs. 9-11.

The interval between sequence boundaries $O x 7$ and $O x 8$ is part of a long-term transgressive trend (Hardenbol et al., 1998), which explains the absence of major hiatuses and allows for a relatively faithful recording of high-frequency sea-level fluctuations. The long-term rising trend of eustatic sea level certainly was synchronous across the Jura platform, which means that the differences in accommodation gain (Figs. 9 and 10) must be due to differences in subsidence rate. The distance between the Gorges de Court and the Mettemberg-Soyhières sections is $16 \mathrm{~km}$ today (Fig. 5B) but was in the order of $30 \mathrm{~km}$ before the folding of the Jura Mountains (Strasser et al., 2015). Allenbach (2001) has shown that synsedimentary tectonic movements were common on the Jura platform during the Oxfordian, and it is reasonable to assume that subsidence rates differed between sections. The general trend of accommodation gain is first similar for both sections, and this can be attributed to a rising trend in eustatic sea level: slow during the deposition of small-scale sequence 0 , then rapidly rising for sequences 1 and 2. Sequences 3 and 4 differ: a continuous gain of $4 \mathrm{~m} / 100 \mathrm{kyr}$ at Mettemberg-Soyhières (Fig. 10) versus $10.3 \mathrm{~m} / 100 \mathrm{kyr}$ then $2.2 \mathrm{~m} / 100 \mathrm{kyr}$ at Gorges de Court (Fig. 9). This rapid accommodation gain at Gorges de Court may be due to a pulse of increased subsidence at this location.

It is interesting to note that the maximum-flooding interval of the medium-scale (405-kyr) sequence formed at the beginning of the rapidly 
rising trend of eustatic sea level, within small-scale sequence 1 (Figs. 8-10). In the sequence-stratigraphic model this would mean that this particular 405-kyr sequence has a thin transgressive and a thick highstand systems tract. Wildi et al. (1989) gave an estimate of Late Jurassic subsidence rates in the southern Jura Mountains of 20 to $40 \mathrm{~m} / \mathrm{Myr}$, i.e., 2 to $4 \mathrm{~m}$ per $100 \mathrm{kyr}$. Subtracting these values from the accommodation gain of 6.2 to $6.6 \mathrm{~m}$ during 100-kyr cycles 1 and 2 (Figs. 9 and 10), there results a eustatic sealevel rise of 2.2 to $4.6 \mathrm{~m}$ per $100 \mathrm{kyr}$ over this time interval.

The uncertainties increase when dealing with the high-frequency sea-level changes. As it can be assumed that high-frequency eustatic sea-level changes were the same over the Jura platform, the discrepancies between the two reconstructed sea-level curves (Fig. 11) must be due to misidentification of the elementary sequences, incorrect decompaction factors, and/or incorrect water depth estimates. During the Oxfordian greenhouse climate, insolation changes probably translated more or less directly into sea-level changes, mainly through thermal expansion and contraction of the volume in the oceanic surface waters (Sames et al., 2016). Sames et al. (2016) suggest that thermal expansion and retraction of ocean water operates on time scales of 1 to 10 '000 years and causes sea-level changes of 5 to $10 \mathrm{~m}$ amplitude. This is well within the time frame of the 20-kyr precession cycle of the Earth's orbit and also corresponds to the meter-scale amplitudes needed to accommodate meter-scale depositional sequences. The insolation curve shown in Fig. 11 is calculated for $30^{\circ} \mathrm{N}$ (Berger, 1990), which is close to the paleolatitude of the Jura platform $\left(26-27^{\circ} \mathrm{N}\right.$; Dercourt et al., 1993). There is no significant change in the frequencies and amplitudes between this curve and the one calculated by Forkner et al. (2010) for their Latemar study at an equatorial position. The curve displays intervals of high amplitudes and intervals of low amplitudes, as it is seen in the reconstructed sea-level curves. The low-amplitude intervals in insolation correspond to the boundaries of the 405-kyr long eccentricity cycle, and also the sea-level amplitudes around medium-scale sequence boundaries $\mathrm{Ox} 7$ and $\mathrm{Ox} 8$ have relatively low amplitudes.

This comparison now allows for a better interpretation of the sedimentary record. It supports the assumption that the elementary sequences are related to the 20-kyr precession cycle and the small-scale sequences to the 100-kyr short eccentricity cycle, and that the interpretation of missing elementary sequences at small-scale sequences boundaries probably is correct. However, the large amplitude change in elementary sequence 16 at Gorges de Court (Fig. 11), that is not seen in Mettemberg-Soyhières, 
may at least partly stem from a misinterpretation of water depth. Following the dolomitization of the sequence-boundary (top of elementary sequence 14) and sequence 15 missing, a lag time probably occurred and the corals at the base of sequence 16 grew in very shallow water. However, also a localized tectonic pulse could have contributed to this discrepancy.

One step further is the analysis of selected elementary sequences, assuming that they formed during 20'000 years and that facies evolution was controlled by a meter-scale sea-level change. Of course, not every elementary sequence can be interpreted in detail, especially if there are no discernible deepening or shallowing facies trends. A good example where an interpretation is possible occurs in the Röschenz Member of the Vorbourg section (Figs. 5 and 6), which has been analysed by Védrine and Strasser (2009), Stienne (2010), and Strasser et al. (2012). Fig. 12 shows the decompacted elementary sequence (from originally $1.1 \mathrm{~m}$ to $2.2 \mathrm{~m}$ ) where both sequence boundaries and the maximum-flooding surface are well developed. The facies analysis is based on continuously sampled rock slabs and 14 thin-sections (Stienne, 2010). The transgressive deposits are carbonate-dominated and contain several discontinuities attributed to reactivation surfaces and incipient hardgrounds. The maximum-flooding surface

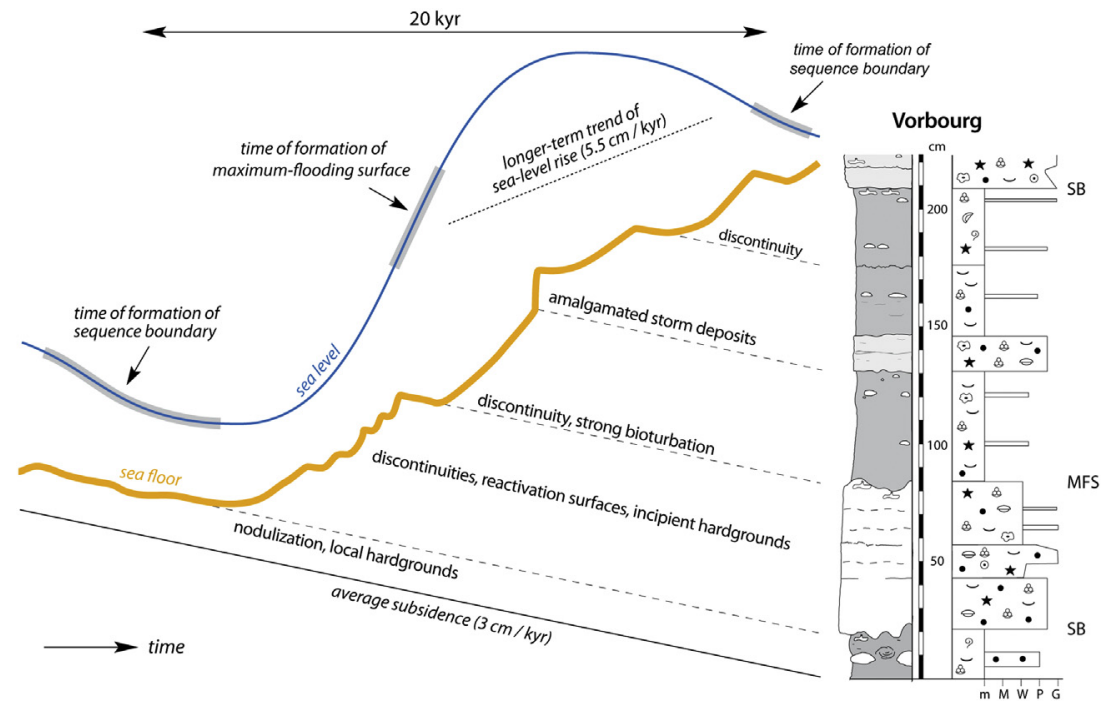

Figure 12 Analysis of one decompacted elementary sequence of the Vorbourg section and interpretation of the sea-level cycle responsible for its deposition (modified from Strasser et al., 2012). Facies symbols as in Fig. 7. MFS, maximum-flooding surface; SB, sequence boundary. For discussion refer to text. 
is strongly bioturbated, suggesting a reduced sedimentation rate. The highstand deposits are marl-dominated and contain an interval of amalgamated storm deposits. The evolution of the sea floor has been reconstructed by assuming varying sedimentation rates depending on the facies interpretation (e.g., slow where hardgrounds formed and at the bioturbated maximumflooding surface, fast for the storm deposits).

The sea-level cycle is assumed to have been symmetrical. Water depth has to be estimated as no intertidal or supratidal facies are present. Subsidence is assumed to have been around $3 \mathrm{~cm} / \mathrm{kyr}$ (Wildi et al., 1989), and a longerterm sea-level rise of $5.5 \mathrm{~cm} / \mathrm{kyr}$ is needed to accommodate the decompacted sequence. The graphical interpretation in Fig. 12 suggests that the fastest rate of short-term sea-level rise was in the order of $30 \mathrm{~cm} / \mathrm{kyr}$ (time of formation of the maximum-flooding surface). This corresponds to $3 \mathrm{~cm} / 100 \mathrm{yr}$, which is still slow when compared to the $20 \mathrm{~cm} / 100 \mathrm{yr}$ rise in modern times (globally averaged sea-level rise over the last 100 years; IPCC, 2014).

Based on the interpretation of sea-floor evolution (Fig. 12), sedimentation rates can be estimated. The $65-\mathrm{cm}$ thick limestone interval (decompacted) at the base of the sequence took about 6000 years to accumulate; the average rate of sediment accumulation thus was in the order of $0.1 \mathrm{~mm} / \mathrm{yr}$. However, sedimentation was interrupted by reactivation events and hardground formation, meaning that sediment production rate certainly was higher because time was lost in the discontinuities (Strasser, 2015). The $110-\mathrm{cm}$ thick marly part of the sequence (without the $15-\mathrm{cm}$ thick amalgamated storm deposits) accumulated within some 10,000 years, giving again an average sedimentation rate of about $0.1 \mathrm{~mm} / \mathrm{yr}$. Sediment production rate, however, must have been higher because time was lost at the discontinuity. Despite the many uncertainties in interpretation, the estimation of sedimentation rates within the short time window offered by cyclostratigraphy gives relatively realistic values that can be compared with the Holocene rates for lagoons of 0.1 to $1 \mathrm{~mm} / \mathrm{yr}$ (Enos, 1991; Strasser and Samankassou, 2003).

\section{CONCLUSIONS}

Modern shallow-water carbonate platforms are complex systems where facies distribution is controlled by multiple hydrological and ecological factors. There is no reason to believe that such platforms were less 
complex in the geological past, and the challenge is to decipher their evolution from the sedimentary record. To do this, the time resolution has to be as high as possible in order to allow for realistic reconstructions and comparisons between ancient and modern environments. Cyclostratigraphy is the tool that has the potential to offer a resolution of 20,000 years (the duration of the orbital precession cycle), which is still low compared to the resolution obtained by, e.g., ${ }^{14} \mathrm{C}$ dating in the Holocene but high for more ancient rock records.

The cyclostratigraphic interpretation of ancient shallow-marine carbonates is not straightforward. Limitations are:

- The insolation signal of the orbital cycles does not necessarily translate directly into climate and/or sea-level changes that are then recorded in the sediment.

- The depositional sequences observed in the sedimentary record may be created by processes other than orbitally controlled climate and/or sea-level changes.

- Hiatuses may lead to "missed beats", and condensations may cause amalgamation of orbitally controlled sequences.

- Depending on the sensitivity of the depositional system, orbital cycles may be recorded faithfully in one place of the platform but not in another, making platform-wide correlations difficult.

- Time-series analyses are difficult to perform because of the common combination of autocyclic and allocyclic processes and the resulting complex facies patterns.

- Chronostratigraphic time control may not be good enough to demonstrate that the observed sequences and their stacking patterns correspond to orbital cyclicity.

Nevertheless, if it can be shown that the observed depositional sequences really formed in tune with orbital cycles, a time window is opened that offers several opportunities:

- The high time-resolution allows estimating the rates of climate and sea-level changes, and comparing with modern rates.

- Sedimentation rates can be estimated.

- The durations of hiatuses and condensations can be evaluated.

- Because eustatic sea-level changes are synchronous across the platform, accommodation changes due to differential subsidence can be identified.

- The evolution of ecosystems and individual organisms can be monitored at a high time resolution. 
- Well-developed depositional sequences can be interpreted in terms of sequence stratigraphy, which gives a dynamic picture of the sedimentary processes.

Based on a good sedimentary record and a detailed facies analysis, and with the many caveats in mind, the cyclostratigraphic analysis of shallowmarine carbonates can thus greatly improve the understanding of their history.

\section{ACKNOWLEDGMENTS}

This study would not have been possible without the yearlong financial support of the Swiss National Science Foundation and the results produced by numerous Msc and $\mathrm{PhD}$ students at the University of Fribourg. I thank Michael Montenari for having invited me to write this book chapter. The constructive comments of Antun Husinec and two anonymous reviewers greatly helped improving the manuscript.

\section{REFERENCES}

Adomat, F., Gischler, E., 2015. Sedimentary patterns and evolution of coastal environments during the Holocene in Central Belize, Central America. J. Coast. Res. 31, 802-826.

Allenbach, R.P., 2001. Synsedimentary tectonics in an epicontinental sea: a new interpretation of the Oxfordian basins of Northern Switzerland. Eclogae Geol. Helv. 94, 265-287.

Bathurst, R.G.C., 1975. Carbonate sediments and their diagenesis. Dev. Sedim. 12, 658.

Bathurst, R.G.C., 1987. Diagenetically enhanced bedding in argillaceous platform limestones: stratified cementation and selective compaction. Sedimentology 34, 749-778.

Berger, A., 1990. Paleo-insolation at the Plio-Pleistocene boundary. Paléobiol. Cont. 17, 1-24.

Berger, A., Loutre, M.F., Dehant, V., 1989. Astronomical frequencies for pre-Quaternary palaeoclimate studies. Terra nova. 1, 474-479.

Berger, A., Loutre, M.F., Laskar, J., 1992. Stability of the astronomical frequencies over the Earth's history for paleoclimate studies. Science 255, 560-566.

Berggren, W.A., Kent, D.V., Aubry, M.P., Hardenbol, J. (Eds.), 1995. Geochronology, Time Scales and Global Stratigraphic Correlation. SEPM Spec. Publ., vol. 54, 386 pp.

Bosence, D., Procter, E., Aurell, M., Bel Kahla, A., Boudagher-Fadel, M., Casaglia, F., Cirilli, S., Mehdie, M., Nieto, L., Rey, J., Scherreiks, R., Soussi, M., Waltham, D., 2009. A dominant tectonic signal in high-frequency, peritidal carbonate cycles? A regional analysis of Liassic platforms from western Tethys. J. Sed. Res. 79, 389-415.

Boulila, S., Hinnov, L.A., Huret, E., Collin, P.-Y., Galbrun, B., Fortwengler, D., Marchand, D., Thierry, J., 2008. Astronomical calibration of the early Oxfordian (Vocontian and Paris basins, France): consequences of revising the Late Jurassic time scale. Earth Planet. Sci. Lett. 276, 40-51.

Boulila, S., Galbrun, B., Hinnov, L.A., Collin, P.Y., Ogg, J.G., Fortwengler, D., Marchand, D., 2010. Milankovitch and sub-Milankovitch forcing of the Oxfordian (Late Jurassic) Terres Noires formation (SE France) and global implications. Basin Res. 22, 717-732.

Boulila, S., Galbrun, B., Miller, K.G., Pekar, S.F., Browning, J.V., Laskar, J., Wright, J.D., 2011. On the origin of Cenozoic and Mesozoic "third-order" eustatic sequences. Earth-Sci. Rev. 109, 94-112. 
Brack, P., Mundil, R., Oberli, F., Meier, M., Rieber, H., 1996. Biostratigraphic and radiometric age data question the Milankovitch characteristics of the Latemar cycles (Southern Alps, Italy). Geology 24, 371-375.

Burgess, P.M., 2006. The signal and the noise: forward modeling of allocyclic and autocyclic processes influencing peritidal carbonate stacking patterns. J. Sed. Res. 76, 962-977.

Burgess, P.M., Wright, V.P., 2003. Numerical forward modeling of carbonate platform dynamics: an evaluation of complexity and completeness in carbonate strata. J. Sed. Res. 73, 637-652.

Carpentier, C., Martin-Garin, B., Lathuilière, B., Ferry, S., 2006. Correlation of reefal Oxfordian episodes and climatic implications in the eastern Paris Basin (France). Terra Nova. 18, 191-201.

Cisne, J.L., 1986. Earthquakes recorded stratigraphically on carbonate platforms. Nature 323, $320-322$.

Cloetingh, S., 1986. Intraplate stresses: a new tectonic mechanism for fluctuations of relative sea level. Geology 14, 617-620.

Colombié, C., Rameil, N., 2007. Tethyan-to-boreal correlation in the Kimmeridgian using high-resolution sequence stratigraphy (Vocontian basin, Swiss Jura, Boulonnais, Dorset). Int. J. Earth Sci. 96, 567-591.

Conrad, C.P., 2013. The solid Earth's influence on sea level. Bull. Geol. Soc. Am. 125, 1027-1052.

Cotillon, P., 1987. Bed-scale cyclicity of pelagic Cretaceous successions as a result of world-wide control. Mar. Geol. 78, 109-123.

De Winter, N.J., Zeeden, C., Hilgen, F.J., 2014. Low-latitude climate variability in the Heinrich frequency band of the Late Cretaceous greenhouse world. Clim. Past. 10, 1001-1015.

Dercourt, J., Ricou, L.E., Vrielynck, B. (Eds.), 1993. Atlas: Tethys Palaeoenvironmental Maps. Gauthier-Villars, Paris.

Dexter, T.A., Kowalewski, M., Read, J.F., 2009. Distinguishing Milankovitch-driven processes in the rock record from stochasticity using computer-simulated stratigraphy. J. Geol. 117, 349-361.

Eberli, G.P., 2013. The uncertainties involved in extracting amplitude and frequency of orbitally driven sea-level fluctuations from shallow-water carbonate cycles. Sedimentology $60,64-84$.

Einsele, G., Ricken, W., 1991. Limestone-marl alternation - an overview. In: Einsele, G., Ricken, W., Seilacher, A. (Eds.), Cycles and Events in Stratigraphy. Springer, Heidelberg, pp. 23-47.

Enay, R., Cariou, E., Debrand Passard, S., Menot, J.-C., Rioult, M., 1980. MiddleOxfordian. In: Enay, R., Mangold, C. (Eds.), Synthèse paléogéographique du Jurassique français, Doc. Lab. Geol. Lyon h.s., vol. 5, pp. 181-184.

Enos, P., 1991. Sedimentary parameters for computer modeling. In: Franseen, E.K., Watney, W.L., Kendall, C.G.StC., Ross, W. (Eds.), Sedimentary Modeling: Computer Simulations and Methods for Improved Parameter Definition, Kansas Geol. Survey Mem., vol. 233, pp. 63-99.

Feng, R., Poulsen, C.J., 2014. Andean elevation control on tropical Pacific climate and ENSO. Paleoceanography 29, 795-809.

Fischer, A.G., 1964. Lofer cyclothems of the alpine Trias. Kans. Geol. Surv. Bull. 169, 107-148. Flügel, E., 2004. Microfacies of Carbonate Rocks. Springer, 976 pp.

Forkner, R.M., Hinnov, L.A., Smart, P., 2010. Use of insolation as a proxy for highfrequency eustasy in forward modeling of platform carbonate cyclostratigraphy - a promising approach. Sed. Geol. 231, 1-13. 
Gale, A.S., Hardenbol, J., Hathway, B., Kennedy, W.J., Young, J.R., Phansalkar, V., 2002. Global correlation of Cenomanian (Upper Cretaceous) sequences: evidence for Milankovitch control on sea level. Geology 30, 291-294.

Gilbert, G.K., 1895. Sedimentary measurement of Cretaceous time. J. Geol. 3, 121-127.

Ginsburg, R.N., 1971. Landward movement of carbonate mud: new model for regressive cycles (abstr.). Bull. Amer. Assoc. Pet. Geol. 55, 340.

Goldhammer, R.K., 1997. Compaction and decompaction algorithms for sedimentary carbonates. J. Sed. Res. 67, 26-35.

Goldhammer, R.K., Dunn, P.A., Hardie, L.A., 1990. Depositional cycles, composite sealevel changes, cycle stacking patterns, and the hierarchy of stratigraphic forcing: examples from Alpine Triassic platform carbonates. Bull. Geol. Soc. Am. 102, 535-562.

Gradstein, F., Ogg, J., Schmitz, M., Ogg, G., 2012. The Geologic Time Scale 2012. Elsevier, $1144 \mathrm{pp}$.

Grotzinger, J.P., 1986. Cyclicity and paleoenvironmental dynamics, Rocknest platform, northwest Canada. Bull. Geol. Soc. Am. 97, 1208-1231.

Gsponer, P., 1999. Etude géologique et sédimentologique de l'anticlinal du Chasseral dans la région de La Heutte (Unpubl. diploma thesis). Univ. Fribourg, 107 pp.

Gygi, R.A., 1995. Datierung von Seichtwassersedimenten des Späten Jura in der Nordwestschweiz mit Ammoniten. Eclogae Geol. Helv. 88, 1-58.

Gygi, R.A., 2000. Integrated stratigraphy of the Oxfordian and Kimmeridgian (Late Jurassic) in northern Switzerland and adjacent southern Germany. Mem. Swiss Acad. Sci. 104, 152.

Gygi, R.A., Coe, A.L., Vail, P.R., 1998. Sequence stratigraphy of the Oxfordian and Kimmeridgian stages (Late Jurassic) in northern Switzerland. SEPM Spec. Publ. 60, 527-544.

Halley, R.B., Harris, P.M., 1979. Fresh-water cementation of a 1,000-year-old oolite. J. Sed. Pet. 49, 969-988.

Haq, B.U., 2014. Cretaceous eustasy revisited. Glob. Planet. Change 113, 44-58.

Hardenbol, J., Thierry, J., Farley, M.B., Jacquin, T., de Graciansky, P.-C., Vail, P.R., 1998. Jurassic sequence chronostratigraphy. In: de Graciansky, P.-C., Hardenbol, J., Jacquin, T., Vail, P.R. (Eds.), Mesozoic and Cenozoic Sequence Stratigraphy of European Basins, SEPM Spec. Publ., 60 chart.

Harris, P.M., Purkis, S.J., Ellis, J., Swart, P.K., Reijmer, J.J.G., 2015. Mapping bathymetry and depositional facies on Great Bahama Bank. Sedimentology 62, 566-589.

Hays, J.D., Imbrie, J., Shackleton, N.J., 1976. Variations in the Earth's orbit: pacemakers of the ice ages. Science 194, 1121-1132.

Hilgen, F.J., Abdul Aziz, H., Krijgsman, W., Raffi, I., Turco, E., 2003. Integrated stratigraphy and astronomical tuning of the Serravallian and lower Tortonian at Monte dei Corvi (Middle-Upper Miocene, northern Italy). Palaeogeo. Palaeoclim. Palaeoeco. 199, 229-264.

Hillgärtner, H., Strasser, A., 2003. Quantification of high-frequency sea-level fluctuations in shallow-water carbonates: an example from the Berriasian-Valanginian (French Jura). Palaeogeo. Palaeoclim. Palaeoeco. 200, 43-63.

Hinnov, L.A., 2013. Cyclostratigraphy and its revolutionizing applications in the Earth and planetary sciences. Geol. Soc. Amer. Bull. 125, 1703-1734.

Hinnov, L.A., Ogg, J.G., 2007. Cyclostratigraphy and the astronomical time scale. Stratigraphy $4,239-251$.

Huang, Z., Ogg, J.G., Gradstein, F.M., 1993. A quantitative study of lower Cretaceous cyclic sequences from the Atlantic Ocean and the Vocontian basin (SE France). Paleoceanography $8,275-291$.

Huang, C., Hinnov, L., Fischer, A.G., Grippo, A., Herbert, T., 2010. Astronomical tuning of the Aptian Stage from Italian reference sections. Geology 38, 899-902. 
Hug, W., 2003. Sequenzielle Faziesentwicklung der Karbonatplattform des Schweizer Jura im Späten Oxford und frühesten Kimmeridge. GeoFocus 7. Fribourg, 156 pp.

Husinec, A., Basch, D., Rose, B., Read, J.F., 2008. FISCHERPLOTS: an Excel spreadsheet for computing Fischer plots of accommodation change in cyclic carbonate successions in both the time and depth domains. Comput. Geosci. 34, 269-277.

Husinec, A., Jelaska, V., 2006. Relative sea-level changes recorded on an isolated carbonate platform: Tithonian to Cenomanian succession, southern Croatia. J. Sed. Res. 76, 1120-1136.

Husinec, A., Read, J.F., 2018. Cyclostratigraphic and $\delta^{13} \mathrm{C}$ record of the lower Cretaceous Adriatic platform, Croatia: assessment of Milankovitch-forcing. Sed. Geol. 373, 11-31.

Immenhauser, A., 2009. Estimating palaeo-water depth from the physical rock record. EarthSci. Rev. 96, 107-139.

International Chronostratigraphic Chart, 2017. www.stratigraphy.org.

IPCC, 2014. Climate Change 2014. Intergovernmental Panel on Climate Change. Synthesis Report. Summary for Policy Makers. http://www.ipcc.ch/report/ar5/syr/.

Kemp, D.B., Sadler, P.M., 2014. Climatic and eustatic signals in a global compilation of shallow marine carbonate accumulation rates. Sedimentology 61, 1286-1297.

Kent, D.V., Muttonic, G., Brack, P., 2004. Magnetostratigraphic confirmation of a much faster tempo for sea-level change for the Middle Triassic Latemar platform carbonates. Earth Planet. Sci. Lett. 228, 369-377.

Laskar, J., Fienga, A., Gastineau, M., Manche, H., 2011. La2010: a new orbital solution for the long-term motion of the Earth. Astronomy Astrophysics 532 (A89), 1-15.

Martinez, M., Deconinck, J.-F., Pellenard, P., Riquier, L., Company, M., Reboulet, S., Moiroud, M., 2015. Astrochronology of the Valanginian-Hauterivian stages (early Cretaceous): Chronological relationships between the Parana-Etendeka large igneous province and the Weissert and Faraoni events. Glob. Planet. Change 131, 158-173.

Matthews, M.D., Perlmutter, M.A., 1994. Global cyclostratigraphy: an application to the Eocene Green River basin. In: de Boer, P., Smith, D.G. (Eds.), Orbital Forcing and Cyclic Sequences, IAS Spec. Publ., vol. 19, pp. 459-481.

Meyers, S.R., 2008. Resolving Milankovitchian controversies: the Triassic Latemar limestone and the Eocene Green River formation. Geology 36, 319-322.

Milankovitch, M., 1941. Kanon der Erdbestrahlung und seine Anwendung auf das Eiszeitenproblem. Acad. Roy. Serbe 133, 633.

Milliman, J.D., Freile, D., Steinen, R.P., Wilber, R.J., 1993. Great Bahama Bank aragonitic muds: mostly inorganically precipitated, mostly exported. J. Sed. Pet. 63, 589-595.

Mitchum Jr., R.M., Van Wagoner, J.C., 1991. High-frequency sequences and their stacking patterns: sequence-stratigraphic evidence of high-frequency eustatic cycles. Sed. Geol. $70,131-160$.

Montañez, I.A., Osleger, D.A., 1993. Parasequence stacking patterns, third-order accommodation events, and sequence stratigraphy of Middle to Upper Cambrian platform carbonates, Bonanza King Formation, southern Great Basin. AAPG Mem. 57, 305-326.

Moore, C.H., 1989. Carbonate diagenesis and porosity. Dev. Sedimentol. 46, 338.

Mundil, R., Brack, P., Meier, M., Rieber, H., Oberli, F., 1996. High resolution U-Pb dating of middle Triassic volcaniclastics: time-scale calibration and verification of tuning parameters for carbonate sedimentation. Earth Planet. Sci. Lett. 141, 137-151.

Ogg, J.G., Coe, A.L., Przybylski, P.A., Wright, J.K., 2010. Oxfordian magnetostratigraphy of Britain and its correlation to Tethyan regions and Pacific marine magnetic anomalies. Earth Planet. Sci. Lett. 289, 433-448.

Osleger, D., 1991. Subtidal carbonate cycles: implications for allocyclic vs. autocyclic controls. Geology 19, 917-920.

Pisias, N.G., Shackleton, N.J., 1984. Modelling the global climate response to orbital forcing and atmospheric carbon dioxide changes. Nature 310, 757-759. 
Pittet, B., 1994. Modèle d'estimation de la subsidence et des variations du niveau marin: Un exemple de l'Oxfordien du Jura suisse. Eclogae Geol. Helv. 87, 513-543.

Pittet, B., 1996. Contrôles climatiques, eustatiques et tectoniques sur des systèmes mixtes carbonates-siliciclastiques de plate-forme: exemples de l'Oxfordien (Jura suisse, Normandie, Espagne) (Ph.D. thesis). Univ. Fribourg, 258 pp.

Pittet, B., Strasser, A., 1998a. Depositional sequences in deep-shelf environments formed through carbonate-mud export from the shallow platform (Late Oxfordian, German Swabian Alb and eastern Swiss Jura. Eclogae Geol. Helv. 91, 149-169.

Pittet, B., Strasser, A., 1998b. Long-distance correlations by sequence stratigraphy and cyclostratigraphy: examples and implications (Oxfordian from the Swiss Jura, Spain, and Normandy). Geol. Rundsch. 86, 852-874.

Pittet, B., Strasser, A., Mattioli, E., 2000. Depositional sequences in deep-shelf environments: a response to sea-level changes and shallow-platform-carbonate productivity (Oxfordian, Germany and Spain). J. Sed. Res. 70, 392-407.

Posamentier, H.W., Allen, G.P., James, D.P., 1992. High-resolution sequence stratigraphy the East Coulee delta, Alberta. J. Sed. Pet. 62, 310-317.

Pratt, B.R., James, N.P., 1986. The St George Group (Lower Ordovician) of western Newfoundland: tidal flat island model for carbonate sedimentation in shallow epeiric seas. Sedimentology 33, 313-343.

Preto, N., Hinnov, L.A., De Zanche, V., Mietto, P., Hardie, L.A., 2004. The Milankovitch interpretation of the Latemar platform cycles (Dolomites, Italy): implications for geochronology, biostratigraphy, and Middle Triassic carbonate accumulation. SEPM Spec. Publ. 81, 167-182.

Purkis, S.J., Rowlands, G.P., Kerr, J.M., 2015. Unravelling the influence of water depth and wave energy on the facies diversity of shelf carbonates. Sedimentology 62, 541-565.

Rankey, E.C., Reeder, S.L., 2010. Controls on platformscale patterns of surface sediments, shallow Holocene platforms. Bahamas. Sedimentol. 57, 1545-1565.

Read, J.F., Kerans, C., Weber, L.J., Sarg, J.F., Wright, F.M., 1995. Milankovitch sea-level changes, cycles, and reservoirs on carbonate platforms in greenhouse and icehouse worlds. Soc. Sed. Geol. Short. Course 35.

Read, J.F., Goldhammer, R.K., 1988. Use of Fischer plots to define third-order sea-level curves in Ordovician peritidal cyclic carbonates. Appalachians. Geol. 16, 895-899.

Rodrigo-Gamiz, M., Martinez-Ruiz, F., Rodriguez-Tovar, F.J., Jimenez-Espejo, F.J., Pardo-Iguzquiza, E., 2014. Millenial- to centennial-scale climate periodicities and forcing mechanisms in the westernmost Mediterranean for the past 20,000 years. Quat. Res. 81, 78-93.

Rodríguez-Tovar, F.J., Pardo-Igúzquiza, E., 2003. Strong evidence of high-frequency (sub-Milankovitch) orbital forcing by amplitude modulation of Milankovitch signals. Earth Planet. Sci. Lett. 210, 179-189.

Romero, O.E., Leduc, G., Vidal, L., Fischer, G., 2011. Millennial variability and long-term changes of the diatom production in the eastern equatorial Pacific during the last glacial cycle. Paleoceanography 26. PA2212.

Sadler, P.M., 1994. The expected duration of upward-shallowing peritidal carbonate cycles and their terminal hiatuses. Bull. Geol. Soc. Am. 106, 791-802.

Saha, R., 2015. Millennial-scale oscillations between sea ice and convective deep water formation. Paleoceanography 30, 1540-1555.

Sames, B., Wagreich, M., Wendler, J.E., Haq, B.U., Conrad, C.P., MelinteDobrinescu, M.C., Hug, X., Wendler, I., Wolfgring, E., Yilmaz, I.Ö., Zorina, S.O., 2016. Review: short-term sea-level changes in a greenhouse world - a view from the Cretaceous. Palaeogeo. Palaeoclim. Palaeoeco. 441, 393-411.

Satterley, A.K., 1996. The interpretation of cyclic successions of the middle and Upper Triassic of the northern and southern Alps. Earth-Sci. Rev. 40, 181-207. 
Schwarzacher, W., 1947. Über die sedimentäre Rhytmik der Dachsteinkalkes von Lofer. Verh. Geol. Bundesanstalt H10-12, pp. 175-188.

Schwarzacher, W., 1993. Cyclostratigraphy and the Milankovitch theory. Dev. Sedimentol. $52,225$.

Schwarzacher, W., 2000. Repetitions and cycles in stratigraphy. Earth-Sci. Rev. 50, 51-75. Shackleton, N.J., 1987. Oxygen isotopes, ice volume and sea level. Quat. Sci. Rev. 6, 183-190. Shinn, E.A., Robbin, D.M., 1983. Mechanical and chemical compaction in fine-grained shallow-water limestones. J. Sed. Pet. 53, 595-618.

Spahn, Z.P., Kodama, K.P., Preto, N., 2013. High-resolution estimate for the depositional duration of the Triassic Latemar Platform: a new magnetostratigraphy and magnetic susceptibility cyclostratigraphy from basinal sediments at Rio Sacuz. Italy. Geochem. Geophys. Geosyst. 14, 1-14.

Stienne, N., 2010. Paléoécologie et taphonomie comparative en milieux carbonatés peu profonds (Oxfordien du Jura Suisse et Holocène du Belize). GeoFocus 22. Fribourg, 248 pp.

Strasser, A., 1991. Lagoonal-peritidal sequences in carbonate environments: autocyclic and allocyclic processes. In: Einsele, G., Ricken, W., Seilacher, A. (Eds.), Cycles and Events in Stratigraphy. Springer, Heidelberg, pp. 709-721.

Strasser, A., 2015. Hiatuses and condensation: an estimation of time lost on a shallow carbonate platform. Dep. Rec. 1, 91-117.

Strasser, A., Hilgen, F.J., Heckel, P.H., 2006. Cyclostratigraphy - concepts, definitions, and applications. Newsl. Stratigr. 42, 75-114.

Strasser, A., Hillgärtner, H., 1998. High-frequency sea-level fluctuations recorded on a shallow carbonate platform (Berriasian and lower Valanginian of Mount Salève, French Jura). Eclogae Geol. Helv. 91, 375-390.

Strasser, A., Hillgärtner, H., Hug, W., Pittet, B., 2000. Third-order depositional sequences reflecting Milankovitch cyclicity. Terra Nova. 12, 303-311.

Strasser, A., Pittet, B., Hillgärtner, H., Pasquier, J.-B., 1999. Depositional sequences in shallow carbonate-dominated sedimentary systems: concepts for a high-resolution analysis. Sed. Geol. 128, 201-221.

Strasser, A., Pittet, B., Hug, W., 2015. Palaeogeography of a shallow carbonate platform: the case of the middle to late Oxfordian in the Swiss Jura Mountains. J. Palaeogeogr. 4, 251-268.

Strasser, A., Samankassou, E., 2003. Carbonate sedimentation rates today and in the past: Holocene of Florida bay, Bahamas, and Bermuda vs. Upper Jurassic and lower Cretaceous of the Jura Mountains (Switzerland and France). Geol. Croat. 56, 1-18.

Strasser, A., Védrine, S., Stienne, N., 2012. Rate and synchronicity of environmental changes on a shallow carbonate platform (Late Oxfordian, Swiss Jura Mountains). Sedimentology $59,185-211$.

Thierry, J., 41 Co-authors, 2000. Early Kimmeridgian (146 - 144 Ma). In: Dercourt, J., et al. (Eds.), Atlas Peri-Tethys. CCGM/CGMW, pp. 85-97.

Tipper, J.C., 1997. Modeling carbonate platform sedimentation - lag comes naturally. Geology 25, 495-498.

Trümpy, R., 1980. Geology of Switzerland, a Guide-book. Part A: An Outline of the Geology of Switzerland. Wepf \& Co., Basel, 104 pp.

Tucker, M.E., Wright, V.P., 1990. Carbonate Sedimentology. Blackwell, 482 pp.

Vail, P.R., Audemard, F., Bowman, S.A., Eisner, P.N., Perez-Cruz, C., 1991. The stratigraphic signatures of tectonics, eustasy and sedimentology - an overview. In: Einsele, G., Ricken, W., Seilacher, A. (Eds.), Cycles and Events in Stratigraphy. Springer, pp. 617-659.

Van Wagoner, J.C., Mitchum, R.M., Campion, K.M., Rahmanian, V.D., 1990. Siliciclastic sequence stratigraphy in Well logs, Cores, and outcrops. Am. Assoc. Pet. Geol. Methods Explor. 7, 55. 
Védrine, S., Strasser, A., 2009. High-frequency palaeoenvironmental changes on a shallow carbonate platform during a marine transgression (Late Oxfordian, Swiss Jura Mountains). Swiss J. Geosci. 102, 247-270.

Wendler, J.E., Wendler, I., 2016. What drove sea-level fluctuations during the midCretaceous greenhouse climate? Palaeogeo. Palaeoclim. Palaeoeco. 441, 412-419.

Westphal, H., Böhm, F., Bornholdt, S., 2004. Orbital frequencies in the carbonate sedimentary record: distorted by diagenesis? Facies $50,3-11$.

Wierzbowski, A., Atrops, F., Grabowski, J., Hounslow, M.W., Matyja, B.A., Olóriz, F., Page, K.N., Parent, H., Mikhail, A., Rogov, M.A., Schweigert, G., Villaseñor, A.B., Wierzbowski, H., WrightJ, K., 2016. Towards a consistent Oxfordian/Kimmeridgian global boundary: current state of knowledge. Vol. Jurassica 14, 15-50.

Wildi, W., Funk, H., Loup, B., Amato, E., Huggenberger, P., 1989. Mesozoic subsidence history of the European marginal shelves of the Alpine Tethys (Helvetic realm, Swiss Plateau and Jura). Eclogae Geol. Helv. 82, 817-840.

Zeeden, C., Meyers, S.R., Lourens, L.J., Hilgen, F.J., 2015. Testing astronomically tuned age models. Paleoceanography 30, 369-383.

Ziegler, P.A., 1990. Geological Atlas of Western and Central Europe. Shell Intern. Petroleum Maatshappij, The Hague, 233 pp.

Zühlke, R., 2004. Integrated cyclostratigraphy of a model Mesozoic carbonate platform the Latemar (middle Triassic, Italy). SEPM Spec. Publ. 81, 183-211.

Zühlke, R., Bechstädt, T., Mundil, R., 2003. Sub-milankovitch and Milankovitch forcing on a model Mesozoic carbonate platform - the Latemar (middle Triassic, Italy). Terra Nova. 15, 69-80. 